\title{
De Hoge Raad in strafzaken uit het Caribische deel van het Koninkrijk
}

\author{
Mr. A.P. Verhaeg*
}

28 oktober 2016, 15/03553 A

(mrs. A.J.A. van Dorst, E.F. Faase en M.J. Borgers en T.N.B.M. Spronken)

ECLI:NL:HR:2016:2453

Last tot teruggave aan verdachte van inbeslaggenomen geldbedrag zonder vast te stellen wat de hoogte van dit bedrag is. Art. 397.1 en art. 145.1 Wetboek van Strafvordering van Sint Maarten (hierna: Sv). Ex art. 397.1 Sv gelast het Hof in het geval van oplegging van straf, tenzij het verklaart tot het geven van zodanige last niet in staat te zijn, dat inbeslaggenomen, nog niet teruggegeven voorwerpen zullen worden teruggegeven aan een met name genoemde persoon, v.zv. zij niet worden verbeurdverklaard of onttrokken aan het verkeer. Ex art. 145.1 Sv is zo'n last tot teruggave gericht tot de bewaarder. Indien de rechter de teruggave van een gedeelte van inbeslaggenomen geldbedragen gelast op de grond dat dit gedeelte aan verdachte toebehoort, kan die teruggave derhalve uitsluitend worden bereikt indien het concreet terug te geven geldbedrag in die last is vermeld. De bestreden uitspraak houdt evenwel niets in m.b.t. de hoogte van het aan verdachte terug te geven geldbedrag, terwijl dit bedrag ook niet ondubbelzinnig kan worden afgeleid uit de stukken.

* $\quad$ Mr. A.P. Verhaegh is stafjurist bij de afdeling strafrecht van het Gerechtshof 's-Hertogenbosch, thans gedetacheerd bij het Gemeenschappelijk Hof van Justitie van Aruba, Curaçao, Sint Maarten en van Bonaire, Sint Eustatius en Saba.

\section{Uitspraak}

op het beroep in cassatie tegen een vonnis van het Gemeenschappelijk Hof van Justitie van Aruba, Curaçao, Sint Maarten en van Bonaire, Sint Eustatius en Saba, van 24 juni 2015, nummer H 14/15, in de strafzaak tegen [verdachte].

\section{Geding in cassatie}

Het beroep is ingesteld door de verdachte. (...)

De Advocaat-Generaal T.N.B.M. Spronken heeft geconcludeerd tot vernietiging van het bestreden arrest, maar uitsluitend voor zover het Hof heeft gelast dat het inbeslaggenomen geld 'voor zover toebehorende aan de verdachte' aan de verdachte wordt teruggegeven, tot zodanige op art. $440 \mathrm{~Sv}$ gebaseerde beslissing als de Hoge Raad gepast zal voorkomen en tot verwerping van het beroep voor het overige.

\section{$(\ldots)$}

3. Beoordeling van het tweede middel

3.1. Het middel klaagt over de door het Hof gegeven last tot teruggave aan de verdachte van een inbeslaggenomen en nog niet teruggegeven geldbedrag.

3.2.1. Het Hof heeft de verdachte ter zake van 'diefstal waarbij de schuldige de goederen onder zijn bereik heeft gebracht door middel van een valse sleutel, meermalen gepleegd' veroordeeld tot een gevangenisstraf van dertig maanden, waarvan zes maanden voorwaardelijk, met een proeftijd van twee jaren, en daarbij de onttrekking aan het verkeer gelast van de inbeslaggenomen betaalpassen, alsmede de teruggave aan de verdachte gelast van inbeslaggenomen voorwerpen. 
3.2.2. De bestreden uitspraak houdt, voor zover voor de beoordeling van het middel van belang, het volgende in:

\section{'Inbeslaggenomen voorwerpen \\ (...)}

Het inbeslaggenomen geld, voor zover toebehorende aan de verdachte, en de inbeslaggenomen telefoon dienen aan de verdachte te worden teruggegeven.

(...)

BESLISSING

Het Hof:

(...)

gelast de teruggave van het inbeslaggenomen geld, voor zover toebehorende aan de verdachte, en de inbeslaggenomen telefoon aan de veroordeelde.'

3.3. Ingevolge art. 397, eerste lid, Wetboek van Strafvordering van Sint Maarten gelast het Hof in het geval van oplegging van straf, tenzij het verklaart tot het geven van zodanige last niet in staat te zijn, dat inbeslaggenomen, nog niet teruggegeven voorwerpen zullen worden teruggegeven aan een met name genoemde persoon, voor zover zij niet worden verbeurdverklaard of onttrokken aan het verkeer. Ingevolge art. 145, eerste lid, van het evengenoemde Wetboek is zo een last tot teruggave gericht tot de bewaarder. Indien, zoals in het onderhavige geval, de rechter de teruggave van een gedeelte van inbeslaggenomen geldbedragen gelast op de grond dat dit gedeelte aan de verdachte toebehoort, kan die teruggave derhalve uitsluitend worden bereikt indien het concreet terug te geven geldbedrag in die last is vermeld. De bestreden uitspraak houdt evenwel niets in met betrekking tot de hoogte van het aan de verdachte terug te geven geldbedrag, terwijl dit bedrag ook niet ondubbelzinnig kan worden afgeleid uit de stukken. Het middel klaagt daarover terecht.

\section{Slotsom}

$\mathrm{Nu}$ de Hoge Raad geen grond aanwezig oordeelt waarop de bestreden uitspraak ambtshalve zou behoren te worden vernietigd, brengt hetgeen hiervoor is overwogen mee dat als volgt moet worden beslist.

\section{Beslissing}

De Hoge Raad:

vernietigt de bestreden uitspraak, maar uitsluitend voor zover het Hof heeft verzuimd de hoogte te bepalen van het aan de verdachte terug te geven geldbedrag;

wijst de zaak terug naar het Gemeenschappelijk Hof van Justitie, opdat de zaak in zoverre op het bestaande hoger beroep opnieuw wordt berecht en afgedaan;

verwerpt het beroep voor het overige.

15 november 2016, 15/01107 UA

(mrs. A.J.A. van Dorst, E.S.G.N.A.I. van de Griend en M.J. Borgers en T.N.B.M. Spronken)

ECLI:NL:HR:2016:2598

Uitlevering aan de V.S. Art. 14, 15 Uitleveringsbesluit van Aruba, Curaçao en Sint Maarten; art. 28.3 Uitleveringswet. Verzoek is gedaan aan Curaçao en aan Sint Maarten. HR: de opvatting dat het hof het aan Sint Maarten gedane verzoek niet in behandeling had mogen nemen omdat het aan Curaçao gedane verzoek reeds in behandeling was genomen, is onjuist. HR ambtshalve: verstaat de bestreden uitspraak aldus dat het advies is gericht aan de gouverneur van Curaçao voor het geval de opgeëiste persoon daar wordt aangetroffen en dat het is gericht aan de gouverneur van Sint Maarten voor het geval dat de o.p. daar wordt aangetroffen. HR ambtshalve: herstelt verzuim de feiten te omschrijven waarvoor de uitlevering kan worden toegestaan ex art. 28, derde lid, Uitleveringswet. AG anders: n-o van de vordering van de procureur-generaal van Curaçao.

\section{Uitspraak}

op het beroep in cassatie tegen een einduitspraak van het Gemeenschappelijk Hof van Justitie van 
Aruba, Curaçao, Sint Maarten en van Bonaire, Sint Eustatius en Saba, van 3 september 2015, nummer HAR 121/13; HAR 121/14, op een verzoek van de Verenigde Staten van Amerika tot uitlevering van [de opgeeiste persoon].

\section{Geding in cassatie}

Het beroep is ingesteld door de opgeëiste persoon. (...)

De Advocaat-Generaal T.N.B.M. Spronken heeft geconcludeerd tot vernietiging van de bestreden uitspraak maar uitsluitend wat betreft het advies aan de Gouverneur van Curaçao tot uitlevering van de opgeëiste persoon aan de Verenigde Staten van Amerika over te gaan en tot niet-ontvankelijkverklaring van de vordering van de procureur-generaal van Curaçao tot advies over de toelaatbaarheid van de uitlevering van de opgeëiste persoon aan de Verenigde Staten van Amerika.

\section{Beoordeling van het vierde middel}

2.1. Het middel klaagt dat art. 6 EVRM en art. 14 en 15 van het Uitleveringsbesluit van Aruba, Curaçao en Sint Maarten zijn geschonden, doordat het Hof zijn advies heeft gericht aan zowel de Gouverneur van Curaçao als de Gouverneur van Sint Maarten.

2.2. Blijkens de toelichting steunt het middel op de opvatting dat, nu het aan Curaçao gerichte verzoek om uitlevering van de opgeëiste persoon reeds in behandeling was genomen, het Hof hetzelfde vervolgens aan Sint Maarten gedane verzoek om uitlevering niet in behandeling had mogen nemen en zijn advies enkel had dienen te richten aan de Gouverneur van Curaçao. Die opvatting is onjuist, zodat het middel faalt.

\section{Beoordeling van de overige middelen}

De middelen kunnen niet tot cassatie leiden. Dit behoeft, gezien art. 81, eerste lid, RO, geen nadere motivering nu de middelen niet nopen tot beantwoording van rechtsvragen in het belang van de rechtseenheid of de rechtsontwikkeling.

\section{Ambtshalve beoordeling van de bestreden uitspraak}

4.1. De bestreden uitspraak vermeldt dat het daarin vervatte advies van het Hof is gericht 'aan de Gouverneurs van Curaçao en Sint Maarten'. De Hoge Raad verstaat de bestreden uitspraak aldus dat het advies is gericht aan de Gouverneur van Curaçao voor het geval dat de opgeëiste persoon in dat land wordt aangetroffen en dat het is gericht aan de Gouverneur van Sint Maarten voor het geval dat de opgeëiste persoon in dat land wordt aangetroffen.

4.2. Het Hof heeft de uitlevering van de opgeëiste persoon aan de Verenigde Staten van Amerika toelaatbaar verklaard ter strafvervolging 'ter zake van voornoemde feiten'.

De bestreden uitspraak behelst evenwel niet een omschrijving van 'voornoemde' feiten waarvoor de uitlevering kan worden toegestaan. De Hoge Raad zal dit verzuim herstellen door de uitlevering toelaatbaar te verklaren voor de feiten die zijn omschreven in na te noemen door de verzoekende Staat bij het uitleveringsverzoek overgelegde stukken.

\section{Slotsom}

$\mathrm{Nu}$ geen van de middelen tot cassatie kan leiden, terwijl de Hoge Raad geen andere dan de hiervoor onder 4 genoemde grond aanwezig oordeelt waarop de bestreden uitspraak ambtshalve zou behoren te worden vernietigd, brengt hetgeen hiervoor is overwogen mee dat als volgt moet worden beslist.

\section{Beslissing}

De Hoge Raad:

vernietigt de bestreden uitspraak maar uitsluitend voor zover het Hof heeft verzuimd de feiten waarvoor de uitlevering kan worden toegestaan, genoegzaam te vermelden;

verklaart de uitlevering toelaatbaar voor de feiten zoals omschreven in de (supplemental) Affidavit in support of request for extradition, van R. Capone, Assistent United States Attorney of the Southern District of New York, van 21 oktober 2013, 27 november 2013 en 18 juni 2014. 
verwerpt het beroep voor het overige.

15 november 2016, 15/03552 A

(mrs. A.J.A. van Dorst, E.F. Faase en M.J. Borgers en T.N.B.M. Spronken)

ECLI:NL:HR:2016:2593

Bijzondere voorwaarde ex art. 17c. $2 \mathrm{Sr}$ Nederlandse Antillen. Hof legt bijzondere voorwaarde op 'dat de verdachte zich gedurende de proeftijd zal gedragen naar de voorschriften en aanwijzingen, te geven door of namens de Reclassering Sint Maarten, zulks zolang deze instelling dat gedurende de proeftijd nodig acht, ook als dat inhoudt dat de verdachte zich gedurende de proeftijd onder klinische dan wel ambulante (psycho-therapeutische) behandeling zal laten stellen, gericht op voorkoming van herhaling van de bewezen verklaarde of soortgelijke misdrijven, zoals behandeling door Turning Point.' HR: de door het hof opgelegde bijzondere voorwaarde is i.s.m. art. 17c, tweede lid, Sr NA v.z.v. deze de beslissing of, en voor welke duur, de verdachte zich gedurende de proeftijd onder klinische behandeling moet laten stellen, in handen legt van Reclassering Sint Maarten (vgl. HR 12 februari 2013, ECLI:NL:HR:2013:BY5449). HR vernietigt de bestreden uitspraak wat betreft de woorden 'klinische dan wel' en verwerpt het beroep voor het overige.

\section{Uitspraak}

op het beroep in cassatie tegen een vonnis van het Gemeenschappelijk Hof van Justitie van Aruba, Curaçao, Sint Maarten en van Bonaire, Sint Eustatius en Saba, van 5 mei 2015, nummer H 203/14, in de strafzaak tegen [verdachte].

\section{Geding in cassatie}

Het beroep is ingesteld door de verdachte. (...)

De Advocaat-Generaal T.N.B.M. Spronken heeft geconcludeerd tot vernietiging van de bestreden uitspraak, maar uitsluitend wat betreft de oplegging van de straf en de maatregelen en tot terugwijzing naar het Gemeenschappelijk Hof van Justitie van Aruba, Curaçao, Sint Maarten en van Bonaire, Sint Eustatius en Saba, opdat de zaak in zoverre op het bestaande hoger beroep opnieuw wordt berecht en afgedaan.

\section{Beoordeling van het middel}

2.1. Het middel klaagt over een door het Hof gestelde bijzondere voorwaarde.

2.2.1. Het Hof heeft de verdachte ter zake van 'handelen in strijd met artikel 6 van de Wegenverkeersverordening' en 'handelen in strijd met artikel 8 van de Wegenverkeersverordening' veroordeeld tot onder meer hechtenis voor de duur van twee maanden, voorwaardelijk met een proeftijd van drie jaren. Het dictum van het bestreden vonnis houdt dienaangaande het volgende in:

'als bijzondere voorwaarde wordt gesteld dat de verdachte zich gedurende de proeftijd zal gedragen naar de voorschriften en aanwijzingen, te geven door of namens de Reclassering Sint Maarten, zulks zolang deze instelling dat gedurende de proeftijd nodig acht, ook als dat inhoudt dat de verdachte zich gedurende de proeftijd onder klinische dan wel ambulante (psycho-therapeutische) behandeling zal laten stellen, gericht op voorkoming van herhaling van de bewezen verklaarde of soortgelijke misdrijven, zoals behandeling door Turning Point.'

2.2.2. Het bestreden vonnis houdt onder het opschrift 'Oplegging van straf' onder meer het volgende in:

'Bij de bepaling van de straf heeft het Hof rekening gehouden met de aard en de ernst van het bewezen en strafbaar verklaarde, met de omstandigheden waaronder de verdachte zich daaraan schuldig heeft gemaakt en met de persoon van de verdachte, zoals van één en ander uit het onderzoek ter terechtzitting in hoger beroep is gebleken. Meer in het bijzonder heeft 
het Hof daarbij het volgende in aanmerking genomen.

De verdachte heeft onder invloed van alcoholhoudende drank een auto bestuurd en daarmee een botsing veroorzaakt. Toen hij een rijverbod opgelegd had gekregen is hij niettemin doorgereden. Dit zijn ernstige wegenverkeersmisdrijven, die in beginsel een vrijheidsbenemende straf rechtvaardigen. Ten nadele van de verdachte geldt dat hij reeds eerder is veroordeeld wegens dronken rijden en het in gevaar brengen van de veiligheid in het verkeer. Op grond van het voorgaande acht het Hof na te melden straf passend en geboden.

Het Hof zal de straf voorwaardelijk opleggen en hier een proeftijd van drie jaren aan verbinden, teneinde de verdachte in te scherpen zich gedurende de proeftijd niet weer aan een strafbaar feit schuldig te maken, alsook om een kader te scheppen waarbinnen de verdachte een behandeling tegen alcoholmisbruik zal kunnen ondergaan. Het Hof acht dit zeer noodzakelijk, nu een eerdere veroordeling wegens een vergelijkbaar feit de verdachte er niet van heeft weerhouden weer de fout in te gaan.'

2.3. De in het bestreden vonnis als te dezen toepasselijk vermelde en ten tijde van het bewezenverklaarde geldende wettelijke voorschriften luiden, voor zover hier van belang, als volgt:

- art. 17a, eerste lid, Wetboek van Strafrecht van de Nederlandse Antillen:

'In geval van veroordeling tot gevangenisstraf van ten hoogste zes jaren, tot hechtenis, vervangende hechtenis daaronder niet begrepen, of tot geldboete, kan de rechter daarbij tevens zowel ten aanzien van die straf als ten aanzien van de opgelegde bijkomende straffen het bevel geven, dat deze geheel of voor een door hem te bepalen gedeelte niet zullen worden ten uitvoer gelegd, tenzij hij later anders mocht gelasten op grond dat de veroordeelde zich voor het einde van een bij het bevel te bepalen proeftijd aan een strafbaar feit heeft schuldig gemaakt dan wel gedurende die proeftijd zich op andere wijze heeft misdragen of een bijzondere voorwaarde, welke bij het bevel mocht zijn gesteld, niet heeft nageleefd.'

- art. 17c, tweede lid, van voormeld wetboek:

'Bij de toepassing van artikel 17a kunnen voorts de volgende bijzonder voorwaarden worden gesteld:

(...)

b. opneming van de veroordeelde in een inrichting ter verpleging gedurende een door de rechter te bepalen termijn, ten hoogste gelijk aan de proeftijd;

(...)

e. andere bijzondere voorwaarden, het gedrag van de veroordeelde betreffende, waaraan deze gedurende de proeftijd of een bij de veroordeling te bepalen gedeelte daarvan, heeft te voldoen.'

2.4.1. Voormeld art. $17 \mathrm{c}$, tweede lid, is gelijkluidend aan art. $14 \mathrm{c}$, tweede lid onder $2^{\circ}$, (oud) van het Nederlandse Wetboek van Strafrecht. In zijn arrest van 12 februari 2013, ECLI:NL:HR:2013:BY5449, NJ 2013/132, heeft de Hoge Raad met betrekking tot deze bepaling het volgende overwogen:

'Ingevolge art. 14c, tweede lid onder $2^{\circ}$, (oud) $\mathrm{Sr}$ kan de voorwaarde tot opneming van de veroordeelde in een inrichting tot verpleging slechts worden opgelegd voor een door de rechter te bepalen termijn. De beslissing of zich de noodzaak voordoet van opneming van de veroordeelde in een inrichting ter verpleging en voor welke duur is voorbehouden aan de rechter (vgl. HR 30 januari 2007, LJN AZ0262, NJ 2007/97).'

2.4.2. Gelet hierop is de door het Hof opgelegde bijzondere voorwaarde, hiervoor onder 2.2.1 weergegeven, voor zover deze de beslissing of, en voor welke duur, de verdachte zich gedurende de proef- 
tijd onder klinische behandeling moet laten stellen, in handen legt van Reclassering Sint Maarten, onverenigbaar met art. $17 \mathrm{c}$, tweede lid, Wetboek van Strafrecht van de Nederlandse Antillen.

2.5. Het middel is terecht voorgesteld.

\section{Slotsom}

$\mathrm{Nu}$ vernietiging op grond van het middel slechts tot na te melden verbetering leidt terwijl de Hoge Raad geen grond aanwezig oordeelt waarop de bestreden uitspraak ambtshalve zou behoren te worden vernietigd, moet als volgt worden beslist.

\section{Beslissing}

De Hoge Raad:

vernietigt de bestreden uitspraak doch uitsluitend wat betreft de in de hiervoor onder 2.2.1 weergegeven beslissing voorkomende woorden 'klinische dan wel';

verwerpt het beroep voor het overige.

\section{Conclusie}

\section{Mr. T.N.B.M. Spronken}

(...)

3.3. Geklaagd wordt dat de opgelegde bijzondere voorwaarde ontoelaatbaar is, omdat het hof het aan de reclassering heeft overgelaten of en zo ja hoe lang de verdachte ook klinisch zou moeten worden behandeld. Nu het gaat om vrijheidsbeneming dient de rechter over de opneming in een kliniek te beslissen en de duur van een dergelijke, intramurale behandeling vast te stellen. Dat mag niet aan de reclassering van Sint Maarten worden overgelaten, aldus de cassatieklacht.

3.4. De bijzondere voorwaarde is gebaseerd op art. Artikel 17c SrNA, zoals dat van toepassing was ten tijde van het bestreden arrest. Deze luidde, voor zover relevant in verband met het middel:

'1. Toepassing van artikel 17a geschiedt onder de algemene voorwaarde, dat de veroordeelde zich voor het einde van de proeftijd niet schuldig maakt aan een strafbaar feit.
2. Bij de toepassing van artikel 17 a kunnen voorts de volgende bijzonder voorwaarden worden gesteld:

(...)

b. opneming van de veroordeelde in een inrichting ter verpleging gedurende een door de rechter te bepalen termijn, ten hoogste gelijk aan de proeftijd;

e. andere bijzondere voorwaarden, het gedrag van de veroordeelde betreffende, waaraan deze gedurende de proeftijd of een bij de veroordeling te bepalen gedeelte daarvan, heeft te voldoen.

3.5. Voor wat betreft de opneming van de veroordeelde in een inrichting ter verpleging komt deze bepaling overeen met de Nederlandse regeling in art. 14 c, lid 2 onder $2^{\circ} \mathrm{Sr}$, zoals die tot 1 april 2012 luidde:

' $2^{\circ}$ opneming van de veroordeelde in een inrichting ter verpleging gedurende een door de rechter te bepalen termijn, ten hoogste gelijk aan de proeftijd;'

3.6. Door de steller van het middel wordt gewezen op twee arresten van de Hoge Raad uit $1990^{1}$ en $2001^{2}$ waarin is bepaald dat de beslissing over de bijzondere voorwaarde tot opneming van de veroordeelde in een inrichting ter verpleging alsmede de duur ervan aan de rechter is voorbehouden en dat de rechter dit niet aan een reclasseringsinstelling mag overlaten. Dit uitgangspunt is in latere jurisprudentie door de Hoge Raad herhaald. ${ }^{3}$ In zijn arrest van 12 februari 2013 heeft de Hoge Raad daarin enige nuancering aangebracht. Het hof had in deze zaak als termijn voor de opneming van de veroordeelde in een klinisch forensische instelling de duur op twee jaren (overeenkomend met de duur

1 HR 6 november 1990, ECLI:NL:HR:1990:AB9573, NJ 1991/274 m.nt G.E. Mulder.

2 HR 2 oktober 2001, ECLI:NL:HR:2001:AB2806.

3 HR 12 december 2006, ECLI:NL:HR:2006:AZ0699, rov. 3.6; HR 30 januari 2007, ECLI:NL:HR: 2007:AZ0262, rov. 3.3.-3.4. 
van de proeftijd) bepaald, 'of zoveel korter als zijn behandelaars in overleg met de reclassering wenselijk achten'. De Hoge Raad oordeelde dat dit niet onverenigbaar is met het bepaalde in de tekst van art. 14c (oud) Sr omdat, zo lees ik het arrest, de rechter in dit geval wel de noodzaak en de maximale duur van de vrijheidsbeneming had vastgesteld. In dit geval achtte de Hoge Raad het redelijk en praktisch dat de rechter het aan de behandelaars overlaat de duur te bekorten, als deze van oordeel zijn dat er op enig moment geen noodzaak meer is de volle termijn van de opneming die de rechter heeft bepaald te benutten. De veroordeelde wordt daarmee niet in zijn belangen geschaad. ${ }^{4}$

3.7. Het laatstgenoemde arrest is ook van belang omdat ten tijde van de uitspraak art. 14c lid 2 onder $2^{\circ}$ Sr was gewijzigd en de Hoge Raad in dit arrest aangeeft hoe hij tegen deze wijziging aankijkt. Sinds 1 april 2012 is in art. $14 \mathrm{c}$ lid 2 onder $10^{\circ} \mathrm{Sr}$ bepaald:

'2. Bij toepassing van artikel 14a kunnen voorts de volgende bijzondere voorwaarden worden gesteld, waaraan de veroordeelde gedurende de proeftijd, of een bij de veroordeling te bepalen gedeelte daarvan, dan wel binnen een door de rechter te bepalen termijn, ten hoogste gelijk aan de proeftijd, heeft te voldoen:

(..)

$10^{\circ}$ opneming van de veroordeelde in een zorginstelling;'

3.8. Wat opvalt is dat in deze bepaling, anders dan in art. $14 \mathrm{c}$ (oud) niet meer met zoveel woorden staat dat de rechter de termijn van de opneming dient

4 HR 12 februari 2013, ECLI:NL:HR:2013:BY5449, rov. 2.3.3. vast te stellen. ${ }^{5}$ Dit staat ook niet meer in de thans geldende wetgeving van Sint Maarten, waarin art. 17 c SrNA, sub b, met ingang van 30 mei 2015 is vervangen door art. 1:21, lid 2, sub g SrNA:

'2. Bij toepassing van artikel 1:19 kunnen voorts de volgende bijzondere voorwaarden worden gesteld, waaraan de veroordeelde gedurende de proeftijd, of een bij de veroordeling te bepalen gedeelte daarvan, dan wel binnen een door de rechter te bepalen termijn, ten hoogste gelijk aan de proeftijd, heeft te voldoen:

(...)

g. opneming van de veroordeelde in een inrichting ter verpleging;'

3.9. In zijn arrest van 12 februari 2013 heeft de Hoge Raad naar aanleiding van deze wetswijziging, AG Vegter in zijn conclusie volgend ${ }^{6}$, in een overweging ten overvloede opgemerkt dat hij zijn rechtspraak over art. 14c (oud) Sr, wat de noodzaak van de opneming en het bepalen van de termijn door de rechter betreft, ook van toepassing acht op het sedert 1 april 2012 geldende art. 14c Sr. Dus ook al staat dat in het tweede lid onder $10^{\circ}$ van art. $14 \mathrm{c}$ Sr niet meer uitdrukkelijk vermeld, de Hoge Raad houdt eraan vast dat alleen de rechter deze bijzondere voorwaarde mag opleggen en hierbij de termijn ervan dient vast te stellen. Dat lijkt mij ook terecht omdat de achter-

5 Dat is eveneens het geval in de thans geldende wetgeving van Sint Maarten waarin art. 17c SrNA, sub b, met ingang van 30 mei 2015 is vervangen door art. 1:21, lid 2, sub g SrNA: "2. Bij toepassing van artikel 1:19 kunnen voorts de volgende bijzondere voorwaarden worden gesteld, waaraan de veroordeelde gedurende de proeftijd, of een bij de veroordeling te bepalen gedeelte daarvan, dan wel binnen een door de rechter te bepalen termijn, ten hoogste gelijk aan de proeftijd, heeft te voldoen: (...) g. opneming van de veroordeelde in een inrichting ter verpleging;".

6 AG Vegter schrijft in zijn conclusie dat de formulering van de vaststelling van de duur in art. $14 \mathrm{c}$ lid 2 onder $10^{\circ}$ weliswaar is gewijzigd, maar dat uit de parlementaire geschiedenis, Kamerstukken II, 32 319, nr. 3, p. 6, niet blijkt dat met deze redactionele wijziging enige materiële verandering is beoogd, maar slechts een codificatie van de bestaande praktijk. 
liggende ratio hiervan is dat vrijheidsbeneming dermate ingrijpend is voor de betrokkene, dat het aan de rechter is om te bepalen of de voorwaarde noodzakelijk is en hoe lang deze (maximaal) kan duren. ${ }^{7}$ Dat de rechter de zorginstelling, c.q. de inrichting ter verpleging ${ }^{8}$ in samenspraak met de reclasseringsinstelling ruimte kan geven de opneming te bekorten, is met het rechtsbeschermende karakter van de bepaling goed te verenigen. Hierdoor kan de vrijheidsbeneming immers alleen maar worden bekort. De voorwaarde blijft dat het de rechter is, die de bandbreedte vaststelt. ${ }^{9}$

3.10. Dan de zaak waar het nu in cassatie om gaat. Het hof heeft in zijn vonnis zoals hiervoor onder 3.2. aangehaald, als bijzondere voorwaarden opgenomen dat de verdachte zich zal houden aan:

'de voorschriften en aanwijzingen, te geven door of namens de Reclassering Sint Maarten, zulks zolang deze instelling dat gedurende de proeftijd nodig acht, ook als dat inhoudt dat de verdachte zich gedurende de proeftijd onder klinische dan wel ambulante (psycho-therapeutische) behandeling zal laten stellen'

3.11. Met de steller van het middel maak ik hieruit op dat het hof met 'klinische behandeling' een opneming ter verpleging in een inrichting heeft bedoeld en dat het hof zowel de noodzaak van een dergelijke opneming als de duur ervan aan de Reclassering Sint Maarten heeft overgelaten. Zoals volgt uit de hiervoor aangehaalde jurisprudentie zijn beide

$7 \quad$ Zie in dit verband de uitgebreide conclusie van AG Knigge ECLI:NL:PHR:2006:AZ0699, onder 13-23, voorafgaand aan HR 12 december 2006, ECLI:NL:HR: 2006:AZ0699.

8 De term "zorginstelling" vervangt de oude termen "inrichting ter verpleging" en hieronder kan hetzelfde worden verstaan, Kamerstukken II, 32 319, nr. 3, p. 21.

9 Zie ook HR 4 maart 2014, ECLI:NL:HR:2014:973, waarin de Hoge Raad de bijzondere voorwaarde die luidde dat de "verdachte zich laat opnemen in een zorginstelling voor een periode van 3 tot maximaal 9 maanden" in stand liet. beslissingen voorbehouden aan de rechter en is dit door het hof miskend.

3.12. Het middel slaagt.

4. Ambtshalve heb ik geen andere gronden aangetroffen die tot vernietiging van de bestreden uitspraak aanleiding behoren te geven.

5. Deze conclusie strekt tot vernietiging van de bestreden uitspraak, maar uitsluitend wat betreft de oplegging van de straf en de maatregelen en tot terugwijzing naar het Gemeenschappelijk Hof van Justitie van Aruba, Curaçao, Sint Maarten en van Bonaire, Sint Eustatius en Saba, opdat de zaak in zoverre op het bestaande hoger beroep opnieuw wordt berecht en afgedaan.

29 november 2016, 15/03556 A

(mrs. A.J.A. van Dorst, E.S.G.NA.I. van de Griend, E.F. Faase en T.N.B.M. Spronken)

ECLI:NL:HR:2016:2719

Hogere gevangenisstraf opgelegd dan wettelijk toegestaan. Skimmen van pinautomaten meermalen gepleegd in periode van 22-9-2014 t/m 25-9-2014 in Sint Maarten, art. 145b en 59 Wetboek van Strafrecht van de Nederlandse Antillen. Hof heeft verdachte veroordeeld tot een gevangenisstraf van dertig maanden, hetgeen in strijd is met deze wettelijke bepalingen. $\mathrm{HR}$ vernietigt wat betreft strafoplegging en wijst in zoverre terug. CAG: anders t.a.v. dictum (HR kan zaak zelf afdoen).

\section{Uitspraak}

op het beroep in cassatie tegen een vonnis van het Gemeenschappelijk Hof van Justitie van Aruba, Curaçao, Sint Maarten en van Bonaire, Sint Eustatius en Saba, van 1 april 2015, nummer H-229/14, in de strafzaak tegen [verdachte].

\section{Geding in cassatie}

Het beroep - dat kennelijk niet is gericht tegen de vrijspraak van het onder 1 tenlastegelegde - is ingesteld door de verdachte. (...) 
De Advocaat-Generaal T.N.B.M. Spronken heeft geconcludeerd tot vernietiging van de bestreden uitspraak maar uitsluitend wat betreft de aan de verdachte opgelegde gevangenisstraf van dertig maanden, tot oplegging aan de verdachte door de Hoge Raad van een gevangenisstraf voor de duur van acht maanden en tot verwerping van het beroep voor het overige.

\section{Beoordeling van het middel}

2.1. Het middel klaagt dat het Hof een hogere gevangenisstraf heeft opgelegd dan wettelijk is toegestaan.

2.2. Ten laste van de verdachte is bewezenverklaard:

'dat hij in of omstreeks de periode van 22 september 2014 tot en met 25 september 2014 in Sint Maarten, meermalen een technisch hulpmiddel om gegevensverkeer af te tappen zoals bedoeld in artikel 145a, eerste lid, van het Wetboek van Strafrecht op een bepaalde plaats, te weten de pinautomaat van de Windward Island Bank bij de Sint Rose Arcade aanwezig heeft doen zijn.'

2.3. De te dezen toepasselijke voorschriften luidden ten tijde van het bewezenverklaarde als volgt:

- art. 145b van het Wetboek van Strafrecht van de Nederlandse Antillen:

'Hij die met het oogmerk dat daardoor gegevensverkeer als bedoeld in artikel 145a, eerste lid, wederrechtelijk wordt afgetapt, een technisch hulpmiddel op een bepaalde plaats aanwezig doet zijn, wordt gestraft met gevangenisstraf van ten hoogste zes maanden of geldboete van ten hoogste vijfentwintigduizend gulden.'

- art. 59 van genoemd Wetboek:

'Bij samenloop van meerdere feiten die als op zich zelve staande handelingen moeten worden beschouwd en meerdere misdrijven opleveren waarop gelijksoortige hoofdstraffen zijn gesteld, wordt één straf uitgesproken.
Het maximum dezer straf is het vereenigd bedrag van de hoogste straffen op de feiten gesteld, doch niet hoger dan een derde boven het zwaarste maximum.'

2.4. Het Hof heeft de verdachte ter zake van het bewezenverklaarde veroordeeld tot een gevangenisstraf van dertig maanden. Deze strafoplegging is in strijd met de zo-even weergegeven wettelijke bepalingen.

2.5. Het middel is derhalve terecht voorgesteld.

\section{Slotsom}

$\mathrm{Nu}$ de Hoge Raad geen grond aanwezig oordeelt waarop de bestreden uitspraak, voor zover aan zijn oordeel onderworpen, ambtshalve zou behoren te worden vernietigd, brengt hetgeen hiervoor is overwogen mee dat als volgt moet worden beslist.

\section{Beslissing}

De Hoge Raad:

vernietigt de bestreden uitspraak, voor zover aan zijn oordeel onderworpen, maar uitsluitend wat betreft de strafoplegging;

wijst de zaak terug naar het Gemeenschappelijk Hof van Justitie, opdat de zaak in zoverre op het bestaande hoger beroep opnieuw wordt berecht en afgedaan;

verwerpt het beroep voor het overige.

\section{Conclusie}

mr. T.N.B.M. Spronken

(...)

3.7. Het middel, waarin wordt gesteld dat de straf die het hof heeft opgelegd het strafmaximum van art. 145b SrNA (oud) in verbinding met art. 59 SrNA (oud) overschrijdt, is terecht voorgesteld. De maximale straf die het hof aan de verdachte kon opleggen is acht maanden gevangenisstraf.

3.8. Onder de aan de Hoge Raad toegezonden stukken bevindt zich onder meer een beschikking van het Gemeenschappelijk Hof van Justitie van Aruba, 
Curaçao, Sint Maarten en van Bonaire, Sint Eustatius en Saba van 13 april 2015, waarin het hof de voorlopige hechtenis van de verdachte in verband met de onderhavige strafzaak met ingang van 25 mei 2015 heeft opgeheven. Uit deze beschikking, die een kleine twee weken na het arrest van het hof van 1 april 2013 is gegeven, wordt - naar aanleiding van hetgeen met betrekking tot de overschrijding van het strafmaximum in het genoemde arrest aan het verzoek tot opheffing van de voorlopige hechtenis ten grondslag is gelegd - overwogen dat:

'het Hof [...] het waarschijnlijk [acht] dat het door verzoeker ingestelde cassatieberoep zal leiden tot vernietiging van het vonnis van het Hof van 1 april 2015' en dat '[het Hof] uitgaande van de maximale gevangenisstraf, gecombineerd met een strafverhoging wegens meerdaadse samenloop, [...] aanleiding [ziet] om de voorlopige hechtenis met ingang van 25 mei 2015 te 14:10 uur op te heffen'.

De in het middel bedoelde overschrijding van het strafmaximum van art. 145b SrNA (oud) in verbinding met art. 59 SrNA (oud) is derhalve reeds aanleiding geweest om de voorlopige hechtenis van de verdachte op te heffen.

3.9. Blijkens de genoemde beschikking heeft het hof vastgesteld dat de verdachte op 25 maart 2015 zes maanden in voorarrest had gezeten. Het hof heeft vervolgens de voorlopige hechtenis met ingang van 25 mei 2015 opgeheven. Ik leid hieruit (het impliciete oordeel) af dat het hof een gevangenisstraf van 8 maanden gepast achtte. Op grond daarvan meen ik dat de Hoge Raad de zaak zelf zal kunnen afdoen door voor de aan de verdachte opgelegde gevangenisstraf van dertig maanden een gevangenisstraf van acht maanden in de plaats te stellen.

3.10. Het middel slaagt. Ambtshalve heb ik geen gronden aangetroffen die tot vernietiging van de bestreden uitspraak aanleiding behoren te geven.

4. Deze conclusie strekt tot vernietiging van de bestreden uitspraak maar uitsluitend wat betreft de aan de verdachte opgelegde gevangenisstraf van dertig maanden, tot oplegging aan de verdachte door de Hoge Raad van een gevangenisstraf voor de duur van acht maanden en tot verwerping van het beroep voor het overige.

\section{4 januari 2017, 15/04366 A}

(mrs. W.A.M. van Schendel, H.A.G. Splintervan Kan, Y. Buruma en A.J.M. Machielse)

ECLI:NL:HR:2017:70

Witwassen in Sint Maarten door geldbedragen voorhanden te hebben in slaapkamer van woning. Verbeurdverklaring geldbedragen. De middelen nemen tot uitgangspunt dat het Hof heeft 'vastgesteld' dat een gedeelte van de in de woning van verdachte aangetroffen geldbedragen een legale herkomst heeft. Dat uitgangspunt berust op een onjuiste lezing van de overwegingen van het Hof. De middelen missen dus feitelijke grondslag, zodat deze niet tot cassatie kunnen leiden.

\section{Uitspraak}

op het beroep in cassatie tegen een vonnis van het Gemeenschappelijk Hof van Justitie van Aruba, Curaçao, Sint Maarten en van Bonaire, Sint Eustatius en Saba, van 16 september 2015, nummer H 80/14, in de strafzaak tegen [verdachte].

\section{Geding in cassatie}

Het beroep is ingesteld door de verdachte. (...)

De Advocaat-Generaal A.J. Machielse heeft geconcludeerd tot verwerping van het beroep.

\section{Beoordeling van het eerste en het tweede middel}

2.1. Het eerste middel klaagt dat uit de bewijsvoering van het Hof niet kan volgen dat de in de bewezenverklaring genoemde geldbedragen geheel uit enig misdrijf afkomstig waren. Het tweede middel klaagt over de verbeurdverklaring van voornoemde geldbedragen. De middelen lenen zich voor gezamenlijke bespreking.

2.2.1. Ten laste van de verdachte is onder 1 bewezenverklaard: 
'dat hij op 1 augustus 2013 in Sint Maarten, voorwerpen, te weten geldbedragen van $\$ 120.460$,- en $€ 68.050$,- voorhanden heeft gehad, terwijl hij wist dat voornoemde geldbedragen - onmiddellijk of middellijk - afkomstig waren van enig misdrijf.'

2.2.2. De bestreden uitspraak houdt het volgende in:

'Bewijsoverwegingen

Nadat er van de DEA informatie was ontvangen dat de woning van de verdachte waarschijnlijk werd gebruikt voor de opslag van drugs, geld en mogelijk wapens, is er bij een daarop volgende huiszoeking verborgen onder het bed in de slaapkamer van de verdachte in tassen een grote hoeveelheid geld, in totaal \$120.460,00 en EUR 68.050,00 aangetroffen. De dollars waren verpakt in vier pakketten, in folie vacuüm verpakte bundels. De euro's waren in een doorzichtige folie in bundels verpakt. In een kledingkast zijn bovendien drie vuurwapens met scherpe patronen en een patroonhouder aangetroffen. De verdachte heeft verklaard dat het geld en de vuurwapens van hem zijn.

Het Hof is van oordeel dat niet aannemelijk is geworden dat het geld onmiddellijk afkomstig is uit een door de verdachte zelf begaan misdrijf. Het dossier biedt daarvoor onvoldoende aanknopingspunten, terwijl de verdachte heeft verklaard dat het geld een legale herkomst heeft en derhalve heeft ontkend dat het geld afkomstig is van een door hemzelf gepleegd misdrijf.

Dat onder een verdachte aangetroffen contant geld uit enig misdrijf afkomstig is, kan, indien op de grond van de beschikbare bewijsmiddelen geen rechtstreeks verband valt te leggen met een bepaald misdrijf, niettemin bewezen worden geacht indien het op grond van de vastgestelde feiten en omstandigheden niet anders kan zijn dan dat het geld uit enig misdrijf afkomstig is. Dat kan het geval zijn indien de verdachte een gerechtvaardigd vermoeden van witwassen niet weerlegt met een in voldoende mate te controleren verklaring waarvan niet al op voorhand kan worden geoordeeld dat deze hoogst onwaarschijnlijk is. De hiervoor weergegeven feiten en omstandigheden zijn van dien aard dat deze, in onderling verband beschouwd, het vermoeden van witwassen rechtvaardigen. Derhalve mag van de verdachte worden verlangd dat hij een verklaring geeft voor de herkomst van het geld, die concreet, enigszins verifieerbaar is en niet op voorhand hoogst onwaarschijnlijk. De verdachte heeft een dergelijke verklaring niet gegeven.

In eerste aanleg heeft de verdachte verklaard dat het geld afkomstig was uit de door zijn drie bedrijven gegenereerde inkomsten, uit de verhuur van een woning te Cay Hill, Sint Maarten en uit de verhuur van een graafmachine op Bonaire. In hoger beroep heeft de verdachte ter terechtzitting een andere lezing gegeven. Hij heeft bij die gelegenheid verklaard dat het geld niet afkomstig is van zijn bedrijven, maar uit de verhuur van voornoemde woning te Cay Hill en de graafmachine en voorts uit de verkoop van auto's en juwelen. Hij zou het geld in twee à drie jaar hebben opgespaard.

Uit het dossier kan weliswaar worden afgeleid dat de verdachte inderdaad verhuurinkomsten uit een woning te Cay Hill en de graafmachine in Bonaire heeft verkregen, maar deze inkomsten bieden een ontoereikend onderbouwde verklaring voor het aangetroffen geldbedrag. De verdachte heeft verklaard dat hij \$1.400,00 per maand aan huurinkomsten ontving en daarvan \$200,00 aan utiliteitskosten per maand betaalde. De verdachte heeft dit niet concreet kunnen maken. Uit de in de auto van de verdachte aangetroffen kwitanties blijkt dat de gemiddelde maandelijkse huurinkomsten niet meer dan $\$ 1.000,00$ bedroegen inclusief utiliteitskosten, terwijl uit de administratie niet afgeleid kan worden dat elke maand huur werd ontvangen. Daarnaast blijkt uit in beslag genomen kwitanties voor betalingen aan het elektriciteitsbedrijf dat de verdachte gemiddeld 
\$ 320,30 per maand aan utiliteitskosten betaalde voor de woning (proces-verbaal van relaas en bevindingen met documentcode 1409180800.AMb met bijbehorende processenverbaal). Zonder rekening te houden met door de verdachte betaalde 'land lease' kosten en uitgaande van drie volle jaren, heeft de verdachte gedurende drie jaar niet meer dan \$24.480,00 ((1000 - 320) x 36 maanden) kunnen sparen uit hoofde van huurinkomsten van de woning te Cay Hill.

De verdachte heeft voorts verklaard dat hij sinds augustus 2011 maandelijks \$3.000,00 voor de graafmachine in Bonaire heeft ontvangen. Ook getuige [getuige] heeft verklaard dat hij \$3.000,00 per maand voor de graafmachine heeft betaald aan de verdachte, evenwel zonder een periode te noemen. De verdachte heeft echter niet verduidelijkt hoe hij het geld vanuit Bonaire contant heeft kunnen ontvangen. De reisbewegingen van de verdachte zijn onderzocht, maar duiden niet op frequente reizen naar Bonaire. Het Hof acht de verklaring op dit punt dan ook niet voldoende concreet en verifieerbaar. Echter, ook al zou uitgegaan worden van de juistheid van de verklaring van de verdachte, dan zou de verdachte gedurende de periode augustus $2011 \mathrm{t} / \mathrm{m}$ juli 2013 $\$ 72.000,00$ aan huurinkomsten van de graafmachine hebben ontvangen, zonder daarbij nog rekening te houden met de door hem gedane investeringen in de graafmachine.

Indien de hiervoor genoemde inkomsten worden opgeteld (nog steeds uitgaande van de juistheid van de verklaring van de verdachte met betrekking tot de graafmachine), komt het Hof uit op een bedrag van $\$ 96.480,00$, terwijl er veel meer geld (meer dan het dubbele) in de woning is aangetroffen. De verdachte heeft weliswaar ook verklaard dat het gespaarde geld mede was opgebouwd uit inkomsten die hij heeft ontvangen uit de verkoop van auto's en juwelen, maar de verdachte is daarover niet concreet geweest en heeft verklaard nooit enige kwitantie of ander document te hebben bewaard. Het Hof acht de verklaring op dit punt dan ook niet concreet en niet verifieerbaar.

De verdachte heeft bovendien geen aannemelijke verklaring gegeven voor de aanwezigheid van het contante geld in zijn woning. Hij heeft in dit verband wel verklaard dat hij het geld in huis bewaarde omdat hij het geld wilde investeren in één van zijn bedrijven, [A] N.V., maar het Hof acht ook deze uitleg onvoldoende concreet, niet verifieerbaar en hoogst onwaarschijnlijk. Te meer daar uit het dossier blijkt dat de verdachte bankrekeningen aanhield op zijn eigen naam en dat ook zijn bedrijven, waaronder het bedrijf [A], bankrekeningen aanhielden.

Concluderend acht het Hof de gegeven uitleg van de verdachte voor de aanwezigheid van het geld niet voldoende concreet en verifieerbaar en bovendien hoogst onwaarschijnlijk en is naar het oordeel van het Hof geen andere conclusie mogelijk dan dat het niet anders kan zijn dan dat het geld onmiddellijk of middellijk uit enig misdrijf afkomstig is en dat de verdachte daarvan op de hoogte was. $\mathrm{Nu}$ niet aannemelijk is geworden dat het geld uit eigen misdrijf afkomstig is, gaat ook het verweer van de verdediging niet op daar waar is betoogd dat het enkele voorhanden hebben van het geld niet voldoende is voor een bewezenverklaring. (...)

In beslaggenomen voorwerpen

(...)

De twee tassen inhoudende dollarbiljetten en eurobiljetten, zullen verbeurd worden verklaard, aangezien feit 1 met betrekking tot dat geld is begaan.'

2.3. De middelen nemen tot uitgangspunt dat het Hof heeft 'vastgesteld' dat een gedeelte groot $\$ 96.480,00$ van de in de woning van de verdachte aangetroffen geldbedragen van \$120.460,00 en $€$ 68.050,00 een legale herkomst heeft. Dat uitgangspunt berust op een onjuiste lezing van de overwe- 
gingen van het Hof. De middelen missen dus feitelijke grondslag, zodat deze niet tot cassatie kunnen leiden.

\section{Beslissing}

De Hoge Raad verwerpt het beroep.

7 maart 2017, 15/01483 A

(mrs. W.A.M. van Schendel, V. van den Brink, A.L.J. van Strien en T.N.B.M. Spronken)

ECLI:NL:HR:2017:375

Openlijke geweldpleging tegen politie op Bonaire, 'met verenigde krachten', art. 147.1 Sr BES. Deze bepaling komt overeen met art. 141.1 (oud) Sr. Voor een veroordeling t.z.v. art. 141.1 (oud) Sr is vereist dat betrokkene deel uitmaakt van een groep die geweld heeft gepleegd en dat van betrokkene zelf in dat verband enige gewelddadige handeling is uitgegaan (ECLI:NL: HR:2001:AD8636, NJ 2001/687). Er bestaat geen grond t.a.v. de vergelijkbare bepaling van het Wetboek van Strafrecht BES anders te oordelen. Het Hof heeft in de bewijsvoering gemotiveerd op grond waarvan naar zijn oordeel het tlgd. 'tezamen en in vereniging' met anderen, openlijk 'met verenigde krachten' geweld plegen bewezen is. 's Hofs oordeel dat de in aanmerking genomen f\&o in hun onderling verband en samenhang voldoende zijn om te kunnen spreken van een bewuste en nauwe samenwerking van verdachte met zijn mededaders geeft niet blijk van een onjuiste rechtsopvatting en is niet onbegrijpelijk. V.zv. het middel klaagt dat van verdachte zelf niet in voornoemde zin enige gewelddadige handeling is uitgegaan nu het aannemen van een gevechtshouding niet als zodanig is te beschouwen, kan het niet tot cassatie leiden omdat het miskent dat het Hof heeft vastgesteld dat het aannemen van een dreigende gevechtshouding gepaard ging met het opzoeken van de confrontatie en zich agressief gedragen, en het daarbij gedurende enige tijd meegaan in een aanvalsgolf van een groep schoppende, slaande en met flessen gooiende personen.

\section{Uitspraak}

op het beroep in cassatie tegen een vonnis van het Gemeenschappelijk Hof van Justitie van Aruba, Curaçao, Sint Maarten en van Bonaire, Sint Eustatius en Saba, van 5 maart 2015, nummer H 198/14, in de strafzaak tegen [verdachte].

\section{Geding in cassatie}

Het beroep is ingesteld door de verdachte. (...)

De Advocaat-Generaal T.N.B.M. Spronken heeft geconcludeerd tot verwerping van het beroep.

\section{Beoordeling van het tweede middel}

2.1. Het middel klaagt onder meer dat de bewezenverklaring voor zover inhoudende dat verdachte openlijk 'met verenigde krachten' geweld heeft gepleegd, niet uit de bewijsvoering kan worden afgeleid.

2.2. Ten laste van de verdachte is bewezenverklaard dat:

'hij, op 20 september 2014, op het eiland Bonaire, tezamen en in vereniging met anderen ter hoogte van de parkeerplaats naast de $\mathrm{MCB}$ te Playa, te weten op de naamloze verbindingsweg tussen Kaya Princes Marie en Kaya L.D. Gerharts, openlijk met verenigde krachten geweld heeft gepleegd

- tegen [verbalisant 1],

- tegen het politievoertuig met kenteken [A-000] en/of het politievoertuig met kenteken [B-000]

welk geweld heeft bestaan uit het gewelddadig, in elk geval met kracht, meermalen althans éénmaal:

- met geschoeide voet schoppen tegen de arm van die [verbalisant 1], en

- slaan, van die [verbalisant 1], en duwen van die [verbalisant 1], en

- gooien van flessen in de richting van die [verbalisant 1],

- gooien van flessen tegen het politievoertuig met kenteken [A-000], en/of het politievoertuig met kenteken [B-000], en 
- in een groep/menigte met een agressieve vechthouding dreigend achter die [verbalisant 1], aanlopen en op die [verbalisant 1] en die [verbalisant 2], en die [verbalisant 3] afgaan, en die [verbalisant 1], omsingelen.'

2.3. Deze bewezenverklaring steunt op de volgende bewijsmiddelen:

'1. Een proces-verbaal van bevindingen van 20 september 2014, inhoudende - zakelijk weergegeven - als verklaring van de verbalisant, de hoofdagent van politie, [verbalisant 1], werkzaam bij het Korps Politie Caribisch Nederland:

Op zaterdag 20 september 2014, omstreeks 01.05 uur, ben ik, verbalisant, in burger gekleed en in mijn vrije tijd, naar mijn privé voertuig gelopen welke geparkeerd stond op de parkeerplaats van de Maduro \& Curiel's Bank. Ik zag dat om en rond mijn auto meerdere personen stonden. Ik zag een groep jongens om mij heen.

[verdachte] en anderen schreeuwden tegen mij dat ik als mariku, makamba terug naar Hulanda moest. Op een gegeven moment zag en voelde ik de menigte steeds dichterbij komen. Ik voelde namelijk dat zij mij aanraakten. Ik heb vervolgens van iemand met kracht een tik, stoot, op mijn linker wang gekregen. Vervolgens zag en voelde ik dat [betrokkene 1] met gestrekt been op mij afkwam, en dat toen ik deze trap met mijn arm probeerde af te weren, zijn voet met schoeisel mijn arm raakte. Ik voelde een brandende pijn. Ik voelde glas tegen mijn blote armen komen. Tevens hoorde ik glazen flessen tegen voertuigen gegooid worden.

2. Een proces-verbaal van bevindingen van 20 september 2014, inhoudende - zakelijk weergegeven - als verklaring van de verbalisant, [verbalisant 2], werkzaam bij het Korps Politie Caribisch Nederland:

Op zaterdag 20 september 2014, omstreeks 01.00 uur, was ik samen met mijn collega's [verbalisant 3] en [verbalisant 4] op patrouille. Wij ontvingen een melding van de meldkamer dat er een auto aan het feveren was ter hoogte van de parkeerplaats naast de MCB gelegen aan de Kaya Grandi te Playa in Bonaire, op de naamloze verbindingsweg tussen Kaya Princes Marie en Kaya L.D. Gerharts. Bij aankomst op de plaats van de melding, omstreeks 1.10 uur, zag ik een grote menigte staan waarvan een deel een blanke man, die ik later herkende als [verbalisant 1] en die onze richting opliep, volgde en uitschold. Ik zag en hoorde dat [verbalisant 1] ernstig bedreigd werd. De personen die het meest agressief tegen [verbalisant 1] waren herkende ik als: [betrokkene 1], [verdachte], [betrokkene 2] en een man met rastaharen die later bleek te zijn [betrokkene 3]. Toen de menigte en [verbalisant 1] zich bij ons surveillanten hadden gevoegd, richtten zich een groot aantal personen tegen ons, geüniformeerde collega's. Op enig moment zag ik dat een voor mij onbekende persoon zijn arm uithaalde en [verbalisant 1] een klap tegen zijn hoofd gaf. Vervolgens zag ik dat [betrokkene 1] met een gestrekt been tegen [verbalisant 1] trapte. Ik zag dat [verdachte], [betrokkene 3] en [betrokkene 2] zich ook met het gevecht gingen bemoeien. Ik zag dat een groot deel van de menigte op ons af kwam. Ik zag dat er flessen in mijn (onze) richting werden gegooid. Ik hoorde deze flessen tegen het dienstvoertuig kapotslaan. Ik voelde mij op dat moment ernstig bedreigd en vreesde voor mijn leven en dat van mijn collega's.

[betrokkene 1], [betrokkene 2] en [verdachte] kwamen terug naar ons en begonnen wederom tegen ons te schreeuwen en te schelden. Ik zag dat collega [verbalisant 3] werd belaagd door [verdachte] en heb mij bij haar gevoegd om haar te verdedigen. Vervolgens richtte [verdachte] zich tegen mij. Hij was zeer agressief en nam een zeer dreigende houding aan tegen mij. Tijdens het wegrijden werden er flessen naar 
ons gegooid welke ik op het dienstvoertuig kapot hoorde slaan.

3. Een proces-verbaal van bevindingen van 20 september 2014, inhoudende - zakelijk weergegeven - als verklaring van de verbalisant, [verbalisant 3], werkzaam bij het Korps Politie Caribisch Nederland:

Op 20 september 2014, omstreeks 01.03 uur, was ik samen met [verbalisant 2] en [verbalisant 4] in de dienstauto [A-000]. Wij ontvingen een melding van feveren en reden richting Kaya Grandi. Wij reden de straat bij de parkeerplaats van de MCB bank in en ik zag dat een groep jongens met een Nederlandse man aan het discussiëren was. Ik zei tegen mijn collega dat de Nederlandse man [verbalisant 1] is. Toen [verbalisant 1] in onze richting kwam, kwam de groep jongens achter [verbalisant 1] aan en begonnen allerlei dingen tegen ons te schreeuwen. $\mathrm{Zij}$ werden steeds agressiever. Ik zag [verdachte], [betrokkene 1], [betrokkene 4], [betrokkene 3] en ene [betrokkene 5] voor mij. [betrokkene 1] had [verbalisant 1] geslagen. Op dat moment kregen de andere jongens de moed om [verbalisant 1] te duwen. Ik zag dat een fles in onze richting werd gegooid. Toen wij wegreden zagen wij dat ze flessen gooiden op onze dienstauto.

4. Een proces-verbaal van bevindingen van 20 september 2014, inhoudende - zakelijk weergegeven - als verklaring van de verbalisant, [verbalisant 5], werkzaam bij het Korps Politie Caribisch Nederland:

Op 20 september 2014 bevond ik verbalisant [verbalisant 5] mij samen met [verbalisant 6] in dienstvoertuig [B-000]. Wij ontvingen een melding van de Centrale Meldkamer om te gaan naar de naamloze verbindingsweg tussen Kaya Princes Marie en Kaya L.D. Gerharts wegens feveren. Bij aankomst ter plaatse zag ik dat een groep jongens een woordenwisseling had met mijn collega [verbalisant 1]. Vervolgens zag ik dat een onbekende man [verbalisant 1] met een gebalde vuist tegen zijn linkerzijde van zijn gezicht had geslagen. Hierna zag ik [betrokkene 1] [verbalisant 1] met gestrekt been slaan. Hierna zag ik dat, een groep mensen samen met [verdachte] en [betrokkene 2] op [verbalisant 1] afging in een dreigende gevechtshouding, om de veiligheid van [verbalisant 1] en mijn andere collega's had ik [verdachte] gepepperd om zijn agressieve gedrag af te breken. Een onbekende had een bierfles op ons gegooid. Hierna zag ik dat [verdachte] op collega [verbalisant 3] afging met een agressieve houding alsof hij met [verbalisant 3] wilde vechten. Ik zag dat [verdachte] kort hierna op [verbalisant 2] afging met een agressieve houding. Op een gegeven moment liepen wij allemaal naar ons dienstvoertuig en reden weg van de plaats delict. Tijdens het weggaan gooiden verschillende mensen bierflessen op de dienstvoertuigen.

5. De eigen waarneming van het Hof van de camerabeelden ter terechtzitting van 12 februari 2015. Op de beelden was te zien:

dat een groep mensen zich bevindt ter hoogte van de parkeerplaats naast de MCB te Playa, te weten op de naamloze verbindingsweg tussen Kaya Princes Marie en Kaya L.D. Gerharts. Dat vanaf het tijdstip 1:22:32 uur een confrontatie tussen de groep en een aantal politieagenten in uniform en politieagent in burger [verbalisant 1] aanvangt. Dat op het tijdstip 1:22:32 uur, 1:23:22 en 1:26:12 uur een man is te zien die zeer op verdachte lijkt. Dat deze man zich in de groep bevindt, op het moment dat [verbalisant 1] door één van de groepsleden wordt geduwd. Dat deze man nadien met een agressieve vechthouding, dreigend op [verbalisant 1] afloopt.

6. De verklaring van de verdachte afgelegd ter terechtzitting in hoger beroep van 12 februari 2015, voor zover inhoudende, - zakelijk weergegeven - : 
Ik was aanwezig toen het incident te Playa plaatsvond. Ik herken mezelf op de camerabeelden op het tijdstip 1:22:32 uur, 1:23:22 en 1:26:12 uur.'

2.4. Het Hof heeft ten aanzien van de bewezenverklaring voorts het volgende overwogen:

'Verdachtes raadsvrouw heeft aangevoerd dat niet wettig en overtuigend kan worden bewezen dat verdachte een significante rol heeft gespeeld bij de tenlastegelegde openlijke geweldpleging en derhalve dient te worden vrijgesproken. De raadsvrouw heeft tevens - kort gezegd - aangevoerd dat verdachte tijdens het geweld niet aanwezig was, althans zich niet met het geweld heeft bemoeid. De verdachte werd ineens door een agent gepepperd en stapte nadien alleen op de politieagenten af om te vragen wat er aan de hand was, aldus de verdediging. Het Hof overweegt het volgende.

Vooropgesteld moet worden dat van 'met verenigde krachten' plegen van geweld in de zin van artikel 147 van het Wetboek van Strafrecht BES sprake is indien de betrokkene een voldoende significante of wezenlijke bijdrage levert aan het geweld, zij het dat deze bijdrage zelf niet van gewelddadige aard behoeft te zijn. De enkele omstandigheid dat iemand aanwezig is in een groep die openlijk geweld pleegt, is niet zonder meer voldoende om hem te kunnen aanmerken als iemand die 'in vereniging' geweld pleegt. Uit de verklaringen van agenten [verbalisant 1], [verbalisant 2], [verbalisant 3], [verbalisant 5] en [verbalisant 7] blijkt dat de verdachte een voldoende significante bijdrage aan het openlijk geweld heeft geleverd. Immers, de verdachte heeft met anderen de gewelddadige confrontatie met de agenten opgezocht en heeft daarbij een dreigende gevechtshouding aangenomen en zich agressief gedragen. De agenten zijn door de groep, waaronder de verdachte, ernstig bedreigd en er is door de groep, waaronder de verdachte, fysiek geweld jegens de agenten toegepast in de vorm van trappen en slaan en het gooien van flessen in de richting van de agenten.

Het Hof constateert uit eigen waarneming ter terechtzitting van de camerabeelden dat een groep mensen zich bevindt ter hoogte van de parkeerplaats naast de MCB te Playa, te weten op de naamloze verbindingsweg tussen Kaya Princes Marie en Kaya L.D. Gerharts. Voorts constateert het Hof dat vanaf het tijdstip 1:22:32 uur het openlijk geweld aanvangt door een confrontatie tussen de groep en een aantal politieagenten in uniform en politieagent in burger [verbalisant 1]. Het Hof heeft uit eigen waarneming geconstateerd dat op het tijdstip 1:22:32 uur, 1:23:22 en 1:26:12 uur een man is te zien die zeer op verdachte lijkt. De verdachte heeft de juistheid van dit vermoeden bevestigd en herkent zichzelf ter terechtzitting van 12 februari 2015 op de camerabeelden. Op grond van het voorgaande stelt het Hof vast dat de in het donker geklede man die zichtbaar is in de tijdspanne 1:22:32 en 1:26:12, verdachte is. Op de camerabeelden is te zien dat de verdachte zich in de groep bevindt, op het moment dat [verbalisant 1] door één van de groepsleden wordt geduwd. De verdachte loopt nadien met een agressieve vechthouding, dreigend af op [verbalisant 1]. Uit de gebezigde bewijsmiddelen is voorts gebleken dat door de groep tevens met flessen is gegooid.

Het Hof is van oordeel dat de verdachte een voldoende significante rol heeft gespeeld bij de tenlastegelegde openlijke geweldpleging. Immers, hij bevindt zich in een groep die jegens politieagenten geweld heeft toegepast, heeft welbewust de confrontatie opgezocht, heeft zich agressief gedragen, is samen met anderen op de agenten afgestapt en heeft een gevechtshouding aangenomen en is bovendien vervolgens gedurende enige tijd meegegaan in de aanvalsgolf van de groep en heeft dusdoende deze groep getalsmatig versterkt. De verdachte is enige tijd van die groep deel uit blijven maken. 
Verdachtes eigen verklaring dat hij dit niet wist en zelf niet agressief heeft gehandeld, wordt door het vorenstaande weerlegd.'

2.5. De tenlastelegging is toegesneden op art. 147, eerste lid, Sr BES. Daarom moeten de in de tenlastelegging voorkomende woorden 'met verenigde krachten' geacht worden aldaar te zijn gebezigd in dezelfde betekenis als daaraan toekomt in het eerste lid van dat artikel.

2.6.1. Art. 147 Sr BES luidt:

'Zij die openlijk met vereenigde krachten geweld plegen tegen personen of goederen worden gestraft met gevangenisstraf van ten hoogste vier jaren en zes maanden (...)'

2.6.2. Deze bepaling komt overeen met art. 141, eerste lid, Sr dat tot de invoering op 12 mei 2000 van de Wet van 25 april 2000, Stb. 2000, 173 tot wijziging van artikel 141 van het Wetboek van Strafrecht luidde:

'Zij die openlijk met verenigde krachten geweld plegen tegen personen of goederen, worden gestraft met gevangenisstraf van ten hoogste vier jaren en zes maanden of geldboete van de vierde categorie.'

2.6.3. Voor een veroordeling ter zake van voormeld art. 141, eerste lid (oud), Sr is vereist dat de betrokkene deel uitmaakt van een groep die geweld heeft gepleegd en dat van betrokkene zelf in dat verband enige gewelddadige handeling is uitgegaan (vgl. HR 10 juli 2001, ECLI:NL:HR:2001:AD8636, NJ 2001/687 rov. 4.6). Er bestaat geen grond ten aanzien van de vergelijkbare bepaling van het Wetboek van Strafrecht BES anders te oordelen.

2.7. Het Hof heeft in de hiervoor onder 2.3 en 2.4 weergegeven bewijsvoering gemotiveerd op grond waarvan naar zijn oordeel het tenlastegelegde 'tezamen en in vereniging' met anderen, openlijk 'met verenigde krachten' geweld plegen bewezen is. Het oordeel van het Hof dat de door hem in aanmerking genomen feiten en omstandigheden in hun onder- ling verband en samenhang voldoende zijn om te kunnen spreken van een bewuste en nauwe samenwerking van de verdachte met zijn mededaders geeft niet blijk van een onjuiste rechtsopvatting en is niet onbegrijpelijk. Voor zover het middel klaagt dat van de verdachte zelf niet in voornoemde zin enige gewelddadige handeling is uitgegaan nu het aannemen van een gevechtshouding niet als zodanig is te beschouwen, kan het niet tot cassatie leiden omdat het miskent dat het Hof heeft vastgesteld dat het aannemen van een dreigende gevechtshouding gepaard ging met het opzoeken van de confrontatie en zich agressief gedragen, en het daarbij gedurende enige tijd meegaan in een aanvalsgolf van een groep schoppende, slaande en met flessen gooiende personen.

2.8. De klacht faalt.

\section{(...)}

4. Beslissing

De Hoge Raad verwerpt het beroep.

21 maart 2017, 15/05234 UA

(mrs. A.J.A. van Dorst, H.A.G. Splinter-van Kan, Y. Buruma, E.S.G.N.A.I. van de Griend, E.F. Faase en D.J.C. Aben)

ECLI:NL:HR:2017:463

\section{Uitspraak}

op het beroep in cassatie tegen een einduitspraak van het Gemeenschappelijk Hof van Justitie van Aruba, Curaçao, Sint Maarten en van Bonaire, Sint Eustatius en Saba, van 3 november 2015, nummer HAR 138/15, op een verzoek van de Verenigde Staten van Amerika tot uitlevering van [de opgeeiste persoon].

\section{De bestreden uitspraak}

Het Hof heeft de uitlevering van de opgeëiste persoon toelaatbaar verklaard ter strafvervolging ter zake van - naar de Hoge Raad begrijpt - de feiten zoals omschreven in de Affidavit in Support of Request for Extradition van Matthew Langley, Assis- 
tant United States Attorney for the Southern District of Florida, van 26 augustus 2015.

\section{Geding in cassatie}

Het beroep is ingesteld door de opgeëiste persoon. (...)

De Advocaat-Generaal D.J.C. Aben heeft geconcludeerd tot verwerping van het beroep.

\section{Beoordeling van het tweede middel}

3.1. Het middel klaagt onder meer over het oordeel van het Hof dat een voltooide inbreuk op art. 6 EVRM niet kan leiden tot ontoelaatbaarverklaring van de gevraagde uitlevering ter strafvervolging.

3.2.1. Blijkens het proces-verbaal van de mondelinge behandeling van het uitleveringsverzoek heeft de raadsvrouwe van de opgeëiste persoon aldaar het woord gevoerd overeenkomstig de door haar overgelegde pleitnotitie. Die pleitnotitie houdt onder 19, 22 en 24 - voor zover voor de beoordeling van het middel van belang - het volgende in:

'19. (...) De politie heeft zodanige druk op [de opgeëiste persoon] uitgeoefend, ook na aanvankelijk weigeren, dat hij is uitgelokt tot het plegen van de feiten als tenlastegelegd in de VS.

22. (...) Er zijn geen indicaties om aan te nemen dat hij zonder actieve uitlokking van de politie wel deze zelfde strafbare feiten zou hebben begaan. In het gedrag van de DEA is de oorzaak van het strafbare feit gelegen, heeft de DEA dit rechtstreeks teweeg gebracht bij [de opgeëiste persoon] en zou het zonder de DEA niet gepleegd zijn. Hun opzet was duidelijk gericht op het bewegen van [de opgeëiste persoon] tot het begaan van dit strafbare feit: het grondfeit. Het wilsbesluit bij [de opgeëiste persoon] is door de DEA opgewekt. Het bewegen van [de opgeëiste persoon] is geschied door geld te beloven en het middel (nepcocaine) te verschaffen. Het nemen van initiatief in het contact met [de opgeëiste persoon] is zijdens de politie, herhaling van aanbod ondanks aanvankelijk afslaan door [de opgeëiste persoon], het bieden van significante bedragen en psychologische druk.

24. (...) [de opgeëiste persoon] zou deze strafbare feiten waarvoor zijn uitlevering wordt gevraagd niet hebben gepleegd als hij niet benaderd was door die DEA-agenten. Er is geen enkele aanleiding om aan te nemen van wel. De DEA is veel verder gegaan dan de passieve rol van undercover agent en heeft hem actief uitgelokt tot het met de politie in zee gaan (...)'

3.2.2. Het aldus aangevoerde is door het Hof als volgt samengevat en verworpen:

'De raadsvrouw heeft zich op het standpunt gesteld dat op grond van artikel 6 van het Verdrag tot bescherming van de rechten van de mens en de fundamentele vrijheden (EVRM) de uitlevering ontoelaatbaar kan worden verklaard indien blijkt dat de opgeëiste persoon door zijn uitlevering zou worden blootgesteld aan een zodanig risico op een flagrante inbreuk op een hem ingevolge artikel 6 EVRM toekomend recht, dat de ingevolge artikel 1 EVRM op Curaçao rustende verplichting om dat recht te verzekeren aan de uitlevering in de weg staat. Volgens de raadsvrouw is in dit geval duidelijk sprake van politiële uitlokking, waardoor op grond van rechtspraak van het Europees Hof voor de Rechten van de Mens aan de opgeëiste persoon van meet af aan het recht op een eerlijk proces is ontnomen en dus het vervolgingsrecht is vervallen. $\mathrm{Nu}$ niet kan worden getoetst of is gehandeld binnen de grenzen van de zogenoemde Tallon-criteria, is de vrees gerechtvaardigd dat op naleving van deze criteria na uitlevering onvoldoende acht zal worden geslagen, aldus de raadsvrouw.

De bevoegdheidsverdeling tussen de rechter die over de toelaatbaarheid van een verzochte uitlevering moet oordelen en de autoriteit die, indien de rechter de uitlevering toelaatbaar heeft geoordeeld, uiteindelijk beslist of en zo ja onder welke condities daadwerkelijk tot uitle- 
vering zal worden overgegaan - in dit geval de Gouverneur van Curaçao - brengt mee dat de rechter op grond van zijn toetsing aan artikel 6 EVRM de uitlevering slechts ontoelaatbaar kan verklaren indien blijkt dat de opgeëiste persoon door zijn uitlevering zou worden blootgesteld aan een zodanig risico van een flagrante inbreuk op enig hem ingevolge artikel 6 EVRM toekomend recht, dat de ingevolge artikel 1 EVRM op Nederland rustende verplichting om dat recht te verzekeren, in de weg staat aan de uit het toepasselijke uitleveringsverdrag voortvloeiende verplichting tot uitlevering (HR 4 april 2006, ECLI:NL:HR:2006:AV8326). Het Hof verwerpt dus het verweer dat vanwege een voltooide inbreuk op artikel 6 EVRM moet worden geconcludeerd tot ontoelaatbaarheid van de uitlevering.

Voor zover het betoog van de raadsvrouw duidt op een mogelijke toekomstige schending, geldt dat aan de rechter die over de toelaatbaarheid van de uitlevering beslist geen oordeel toekomt over de rechtmatigheid van de bewijsgaring ten behoeve van de strafzaak in de verzoekende staat (HR 9 december 2014, ECLI:NL:HR: 2014: 3540 en 3543). Het standpunt van de raadsvrouw dat dit geval zich onderscheidt van dat in het hiervoor bedoelde arrest omdat het recht op vervolging (in de zin van de ontvankelijkheid van de vervolgende instantie) ter discussie staat en dus niet de rechtmatigheid van de bewijsvergaring, is niet steekhoudend. In beide gevallen gaat het om het al dan niet rechtmatig inzetten van opsporingsmiddelen en niet om de mogelijke consequenties van onrechtmatigheid daarvan, zoals het vervallen van het vervolgingsrecht of bewijsuitsluiting.'

3.3. Het middel klaagt terecht dat's Hofs kennelijke oordeel dat uit HR 4 april 2006, ECLI:NL:HR: 2006:AV8326, NJ 2006/408 moet worden afgeleid dat 'een voltooide inbreuk op artikel 6 EVRM' nimmer kan leiden tot ontoelaatbaarverklaring van de gevraagde uitlevering ter strafvervolging, steunt op een onjuiste lezing van dat arrest. De Hoge Raad vindt hierin aanleiding zijn jurisprudentie met betrekking tot verweren over - kort gezegd - mensenrechtenschendingen in uitleveringszaken op hoofdlijnen samen te vatten.

3.4. De hier relevante verdragsbepalingen luiden - voor zover hier van belang - in de Nederlandse vertaling als volgt:

- art. 6, eerste lid, EVRM:

'Bij het vaststellen van zijn burgerlijke rechten en verplichtingen of bij het bepalen van de gegrondheid van een tegen hem ingestelde vervolging heeft een ieder recht op een eerlijke en openbare behandeling van zijn zaak, binnen een redelijke termijn, door een onafhankelijk en onpartijdig gerecht dat bij de wet is ingesteld.'

- art. 13 EVRM:

'Een ieder wiens rechten en vrijheden die in dit Verdrag zijn vermeld, zijn geschonden, heeft recht op een daadwerkelijk rechtsmiddel voor een nationale instantie, ook indien deze schending is begaan door personen in de uitoefening van hun ambtelijke functie.'

- art. 2, derde lid aanhef en onder a, IVBPR:

'Iedere Staat die partij is bij dit Verdrag verbindt zich:

a) Te verzekeren dat een ieder wiens rechten of vrijheden als in dit Verdrag erkend, worden geschonden een effectief rechtsmiddel ter beschikking heeft, zelfs indien de schending zou zijn begaan door personen in de uitoefening van hun ambtelijke functie.'

- art. 14, eerste lid, IVBPR:

'Bij het bepalen van de gegrondheid van een tegen hem ingestelde strafvervolging, of het vaststellen van zijn burgerlijke rechten en verplichtingen in een rechtsgeding, heeft een ieder recht op een eerlijke en openbare behandeling 
door een bevoegde, onafhankelijke en onpartijdige bij de wet ingestelde rechterlijke instantie.'

3.5. Uitgangspunt in uitleveringszaken is dat bij de beoordeling van een uitleveringsverzoek dat is gebaseerd op een uitleveringsverdrag, in beginsel moet worden uitgegaan van het vertrouwen dat de verzoekende Staat bij de vervolging en berechting van de opgeëiste persoon de daarop betrekking hebbende fundamentele rechten welke zijn neergelegd in het EVRM en het IVBPR zal respecteren (vgl. HR 8 juli 2003, ECLI:NL:HR:2003:AE5288). Volgens bestendige jurisprudentie van de Hoge Raad is in uitleveringszaken - gelet op het systeem van de Uitleveringswet (hierna: UW), zoals daarvan blijkt uit de art. 8 en 10 UW, en de geschiedenis van de totstandkoming van die wet - het oordeel omtrent de vraag of de verzochte uitlevering moet worden geweigerd wegens een gegrond vermoeden dat bij inwilliging van het verzoek de opgeëiste persoon zal worden blootgesteld aan een dreigende inbreuk op zijn fundamentele rechten als bedoeld in onder meer art. 3 EVRM voorbehouden aan de Minister van Veiligheid en Justitie en zal hij bij een bevestigend antwoord het verzoek tot uitlevering moeten afwijzen. Indien evenwel komt vast te staan dat in de zaak waarvoor de uitlevering van de opgeëiste persoon is gevraagd, sprake is van een voltooide inbreuk op zijn fundamentele rechten, is het de uitleveringsrechter die de verzochte uitlevering ontoelaatbaar dient te verklaren. Er bestaat geen goede grond ten aanzien van die bevoegdheidstoedeling anders te oordelen in zaken waarin het Uitleveringsbesluit van Aruba, Curaçao en Sint Maarten van toepassing is, zij het dat het dan de Gouverneur is die de taken en bevoegdheden heeft welke de UW aan de Minister toekent.

3.6. Bij een beroep op een inbreuk op de fundamentele rechten die de opgeëiste persoon in art. 6 EVRM zijn toegekend, geldt het volgende.

A Indien het gaat om een verzoek tot uitlevering ter tenuitvoerlegging van een rechterlijke veroordeling en wordt aangevoerd dat in de zaak die tot die veroordeling heeft geleid, een flagrante inbreuk is gemaakt op art. 6, eerste lid, EVRM, is het aan de uitleveringsrechter te beslissen over de vraag of enig in die verdragsbepaling gegarandeerd recht van de opgeëiste persoon is geschonden. Dit is niet anders indien het gaat om een beroep op een flagrante inbreuk op art. 14, eerste lid, IVBPR. Het gaat hier dus om een beroep op een voltooide flagrante schending van voormelde verdragsbepaling(en).

B i Indien het gaat om een verzoek tot uitlevering ter strafvervolging en wordt aangevoerd dat in de desbetreffende strafzaak inbreuk dreigt te worden gemaakt op art. 6, eerste lid, EVRM en/of art. 14, eerste lid, IVBPR, is het in de regel niet aan de uitleveringsrechter te oordelen over de gegrondheid van zo een beroep op een dreigende mensenrechtenschending. In een dergelijk geval moet in beginsel worden uitgegaan van het vertrouwen dat de verzoekende Staat deze verdragsbepaling(en) zal eerbiedigen. Zo een verweer kan dus niet leiden tot ontoelaatbaarverklaring van de gevraagde uitlevering, zij het dat de uitleveringsrechter in het aangevoerde grond kan vinden de Minister in zijn advies als bedoeld in art. 30 UW, dan wel de Gouverneur deelgenoot te maken van zijn opvatting omtrent het aan het uitleveringsverzoek te geven gevolg, waaronder in voorkomende gevallen begrepen het vragen van garanties aan de verzoekende Staat om een dergelijke dreigende schending te voorkomen.

ii Op grond van het vertrouwensbeginsel moet voorts worden aangenomen dat het rechtssysteem van de verzoekende Staat de opgeëiste persoon in staat stelt om na diens uitlevering ter strafvervolging een beroep op een mensenrechtenschending voor te leggen aan de rechter van de verzoekende Staat en dat deze daar dan een oordeel over geeft met het oog op de waarborging van het recht van de opgeëiste persoon op een eerlijk proces als bedoeld in art. 6, eerste lid, EVRM en/of art. 14, eer- 
ste lid, IVBPR. Daarbij verdient opmerking dat in geval van een uitlevering ter strafvervolging de vraag of inbreuk is gemaakt op het recht van de opgeëiste persoon op een eerlijk proces, in de regel eerst kan worden beantwoord na de uitspraak van de strafrechter in de verzoekende Staat, omdat pas dan kan worden vastgesteld of de mensenrechtenschending niet (meer) vatbaar was voor herstel of compensatie. De uitleveringsrechter kan daarom in de regel niet toekomen aan de inhoudelijke beoordeling van een verweer dat sprake is van een reeds voltooide schending van art. 6, eerste lid, EVRM en/of art. 14, eerste lid, IVBPR.

iii Het uitgangspunt dat in de gevallen waarin de uitlevering ter strafvervolging is gevraagd, de uitleveringsrechter in beginsel niet inhoudelijk oordeelt over een beroep op dreigende en/of voltooide mensenrechtenschendingen, kan evenwel uitzondering lijden indien naar aanleiding van een bij de behandeling van het uitleveringsverzoek ter zitting voldoende onderbouwd verweer is komen vast te staan

a dat de opgeëiste persoon door zijn uitlevering zal worden blootgesteld aan het risico van een flagrante inbreuk op enig hem ingevolge deze verdragsbepalingen toekomend recht, en tevens

b dat hem na zijn uitlevering ter zake van die inbreuk niet een rechtsmiddel als bedoeld in art. 13 EVRM respectievelijk art. 2, derde lid aanhef en onder a, IVBPR ten dienste staat.

In zo een geval staat de op de landen van het Koninkrijk rustende verplichting om de uit voormelde verdragsbepaling(en) voortvloeiende rechten van de opgeëiste persoon te verzekeren in de weg aan de nakoming van de verdragsrechtelijke verplichting tot uitlevering. Op grond van voormelde bevoegdheidstoedeling is het derhalve - kort gezegd - de uitleveringsrechter die tot oordelen is geroepen ingeval bij de behandeling van het uitleveringsverzoek ter zitting beroep is gedaan op het (dreigende) risico van een flagrante inbreuk op art. 6, eerste lid, EVRM onderscheidenlijk art. 14, eerste lid, IVBPR, doch uitsluitend indien tevens is aangevoerd dat en waarom de opgeëiste persoon na zijn uitlevering niet een rechtsmiddel als vorenbedoeld ten dienste staat.

Daarbij moet worden aangetekend dat uit de rechtspraak van het EHRM volgt dat niet snel wordt aangenomen dat sprake is van blootstelling aan het risico van een flagrante inbreuk op art. 6, eerste lid, EVRM die moet leiden tot ontoelaatbaarverklaring van de gevraagde uitlevering ter strafvervolging. In dat verband kan worden gewezen op EHRM 17 januari 2012, Othman tegen V.K., nr. 8139/09, NJ 2013/360, rov. 259 waar gevallen zijn opgesomd waarin sprake is van een 'flagrant denial of justice'.

3.7. Uit het vorenoverwogene volgt dat het middel terecht klaagt dat het Hof het gevoerde verweer op ondeugdelijke gronden heeft verworpen. De gegrondheid van het middel behoeft evenwel niet tot cassatie te leiden omdat het Hof het verweer dat de opgeëiste persoon door overheidsfunctionarissen van de verzoekende Staat is uitgelokt tot het begaan van de strafbare feiten waarvoor zijn uitlevering is verzocht (de zogenoemde entrapment defense in het Amerikaanse recht), slechts had kunnen verwerpen. Gelet op hetgeen hiervoor in $3.6 \mathrm{sub}$ $\mathrm{B}$ onder (ii) is vooropgesteld, komt de uitleveringsrechter immers bij een verzoek tot uitlevering ter strafvervolging in de regel niet toe aan de inhoudelijke beoordeling van een verweer over een reeds voltooide schending van art. 6, eerste lid, EVRM en/ of art. 14, eerste lid, IVBPR. Nu door of namens de opgeëiste persoon niet is aangevoerd dat zich de in 3.6 sub B onder (iii) bedoelde situatie zal voordoen, lijdt die regel in casu geen uitzondering.

3.8. De klacht is tevergeefs voorgesteld.

(...) 


\section{Beslissing}

De Hoge Raad verwerpt het beroep.

21 maart 2017, 16/01894 UA

(mrs. A.J.A. van Dorst, E.S.G.N.A.I. van de Griend, E.F. Faase en D.J.C. Aben)

ECLI:NL:HR:2017:464

Toevoeging van een andere raadsman aan de opgeëiste persoon bij ontstentenis van de toegevoegde raadsman. Art. 24.3 Uitleveringswet; art. 14 Uitleveringsbesluit van Aruba, Curaçao en Sint Maarten. De voorzitter van het hof is gehouden een last tot aanwijzing van een raadsman te geven in geval de opgeëiste persoon geen raadsman heeft. Het hof had moeten doen blijken te hebben onderzocht of de bij de mondelinge behandeling van het uitleveringsverzoek verschenen o.p. het verlangen had zich door de reeds toegevoegde raadsman te laten bijstaan of zich van een nieuwe raadsman te voorzien (vgl. HR 11 oktober 2005, ECLI:NL: HR:2005:AU2694). Volgt vernietiging en terugwijzing.

\section{Uitspraak}

op het beroep in cassatie tegen een einduitspraak van het Gemeenschappelijk Hof van Justitie van Aruba, Curaçao, Sint Maarten en van Bonaire, Sint Eustatius en Saba, van 3 november 2015, nummer HAR 137/15, op een verzoek van de Verenigde Staten van Amerika tot uitlevering van [de opgeeiste persoon].

\section{De bestreden uitspraak}

Het Hof heeft de uitlevering van de opgeëiste persoon toelaatbaar verklaard ter strafvervolging ter zake van - naar de Hoge Raad begrijpt - de feiten zoals omschreven in de Affidavit in Support of Request for Extradition van Matthew Langley, Assistant United States Attorney for the Southern District of Florida, van 26 augustus 2015.

\section{Geding in cassatie}

Het beroep is ingesteld door de opgeëiste persoon. (...)

De Advocaat-Generaal D.J.C. Aben heeft geconcludeerd tot vernietiging van de bestreden uitspraak en tot terugwijzing van de zaak naar het Gemeenschappelijk Hof van Justitie teneinde de toelaatbaarheid van de verzochte uitlevering opnieuw te beoordelen.

\section{Beoordeling van het eerste middel}

3.1. Het middel klaagt dat het Hof ten onrechte niet een raadsman heeft toegevoegd aan de opgeëiste persoon.

3.2. Blijkens het proces-verbaal van de mondelinge behandeling van het verzoek tot uitlevering was de opgeëiste persoon ten tijde van die behandeling uit anderen hoofde gedetineerd. Uit dat proces-verbaal blijkt niet dat de aldaar verschenen opgeëiste persoon door een raadsman is bijgestaan noch dat de voorzitter van het Hof een last tot toevoeging van een raadsman heeft gegeven, zodat het ervoor moet worden gehouden dat zulks niet is geschied, terwijl evenmin blijkt dat de opgeëiste persoon geen prijs stelde op rechtsbijstand.

3.3. Voor de beoordeling van het middel zijn de volgende bepalingen van belang.

- Art. 24, eerste en derde lid, van de Nederlandse Uitleveringswet (hierna: UW):

'1. Dadelijk na de ontvangst van de in artikel 23 bedoelde vordering bepaalt de voorzitter van de rechtbank, zoveel mogelijk bij voorrang, het tijdstip waarop de opgeëiste persoon door de rechtbank zal worden gehoord. Hij kan daarbij diens medebrenging bevelen.

3. In geval de opgeëiste persoon geen raadsman heeft, geeft de voorzitter aan het bestuur van de raad voor rechtsbijstand last tot aanwijzing van een raadsman.' 
- Art. 25, derde lid, UW:

'Bij zijn verhoor kan de opgeëiste persoon zich door zijn raadsman doen bijstaan.'

-Art. 45a, eerste lid, UW:

'De opgeëiste persoon heeft het recht zich door een raadsman te doen bijstaan. De artikelen (...) 43 tot en met 45 (...) van het Wetboek van Strafvordering zijn van overeenkomstige toepassing.'

- Art. 44, eerste en tweede lid, van het Nederlandse Wetboek van Strafvordering (hierna: Sv):

'1. Bij verhindering of ontstentenis van de aangewezen raadsman treft deze een voorziening voor zijn waarneming; indien blijkt dat dit niet is geschied, wordt zo nodig voor de verdachte onverwijld een andere raadsman aangewezen.

2. Blijkt van de verhindering of ontstentenis van de aangewezen raadsman pas op de terechtzitting, dan geeft de voorzitter last tot aanwijzing van een andere raadsman.'

- Art. 65, eerste lid, Wetboek van Strafvordering van Curaçao (hierna: Sv Curaçao):

'Bij verhindering of ontstentenis van de toegevoegde raadsman wordt de verdachte een andere raadsman toegevoegd. De toegevoegde raadsman geeft van zijn verhindering of ontstentenis kennis aan de instantie die met de toevoeging is belast.'

- Art. 14, eerste en derde lid, van het Uitleveringsbesluit van Aruba, Curaçao en Sint Maarten (hierna: Uitleveringsbesluit):

'1. Het verhoor geschiedt in het openbaar, tenzij de opgeëiste persoon de behandeling der zaak met gesloten deuren verlangt, of het Hof, om gewichtige redenen, bij het proces-verbaal der zitting te vermelden, beveelt, dat het geheel of gedeeltelijk met gesloten deuren zal plaats hebben.

3. De opgeëiste persoon is bevoegd zich door een raadsman te doen bijstaan.'

3.4. Het Uitleveringsbesluit kent niet een bepaling als art. 24, derde lid, UW inhoudende dat, ingeval de opgeëiste persoon geen raadsman heeft, de voorzitter van het gerecht ambtshalve een last tot aanwijzing van een raadsman geeft.

3.5. Uit de parlementaire geschiedenis van - thans de Rijkswet cassatierechtspraak in uitleveringszaken voor Aruba, Curaçao en Sint Maarten volgt dat de rijkswetgever zoveel mogelijk heeft willen aansluiten bij het systeem van het Nederlandse uitleveringsrecht en met name ook bij de jurisprudentie van de Hoge Raad.

3.6. Tegen de achtergrond van deze wetsgeschiedenis moet worden aangenomen dat onder de vigeur van voormeld Uitleveringsbesluit de voorzitter van het Hof gehouden is een last tot aanwijzing van een raadsman te geven ingeval de opgeëiste persoon geen raadsman heeft.

3.7. Het in het belang van de opgeëiste persoon gegeven voorschrift vervat in art. 24, derde lid, UW is van zo wezenlijke betekenis dat, al wordt dit niet uitdrukkelijk in het Uitleveringsbesluit bepaald, de niet-nakoming daarvan geacht moet worden aan een geldige behandeling van het uitleveringsverzoek in de weg te staan.

3.8. Indien het Hof heeft geoordeeld dat het Uitleveringsbesluit niet een gehoudenheid inhoudt als hiervoor onder 3.6 weergegeven, klaagt het middel daarover terecht.

3.9. Indien het Hof ervan is uitgegaan dat reeds een last tot toevoeging van een raadsman was gegeven omdat de opgeëiste persoon uit anderen hoofde was gedetineerd, geldt het volgende. Gelet op hetgeen hiervoor onder 3.6 is overwogen en in aanmerking genomen dat art. $44 \mathrm{~Sv}$ in art. 45 a, eerste lid, UW van overeenkomstige toepassing is verklaard, is art. 44, eerste lid, Sv, dat grotendeels dezelfde inhoud heeft als art. 65, eerste lid, Sv Curaçao, ook in de onderhavige zaak van belang. 
3.10. De Hoge Raad heeft in zijn arrest van 11 oktober 2005, ECLI:NL:HR:2005:AU2694, geoordeeld dat art. 45, eerste lid, (oud) Sv - thans art. 44, eerste lid, $\mathrm{Sv}$ - aldus moet worden uitgelegd dat bij verhindering of ontstentenis van de toegevoegde raadsman in de regel aan de verdachte een andere raadsman moet worden toegevoegd en dat daarvan slechts in bijzondere gevallen kan worden afgezien.

3.11. Gelet hierop en in aanmerking genomen de onder 3.2 vermelde omstandigheden had het Hof moeten doen blijken te hebben onderzocht of de bij de mondelinge behandeling van het uitleveringsverzoek verschenen opgeëiste persoon het verlangen had zich door de reeds toegevoegde raadsman te laten bijstaan of zich van een nieuwe raadsman te voorzien. Voor zover het middel daarover klaagt, is het eveneens terecht voorgesteld.

\section{Slotsom}

Hetgeen hiervoor is overwogen brengt mee dat de bestreden uitspraak niet in stand kan blijven, de overige middelen geen bespreking behoeven en als volgt moet worden beslist.

\section{Beslissing}

De Hoge Raad:

vernietigt de bestreden uitspraak;

wijst de zaak terug naar het Gemeenschappelijk Hof van Justitie, opdat opnieuw zal worden beslist op het verzoek tot uitlevering van de opgeëiste persoon.

\section{8 april 2017, 16/01895 A}

\section{(Mr. A.J.A. van Dorst en E.J. Hofstee)}

ECLI:NL:HR:2017:709

Rolbeslissing. Betekening van de aanzegging in cassatie ex art. $435 \mathrm{~Sv}$ in Sint Maarten. Op de gronden vermeld in de conclusie A-G moet worden aangenomen dat de uitreiking van de aanzegging a.b.i. art. $435 \mathrm{~Sv}$ niet op rechtsgeldige wijze heeft plaatsgevonden, zodat de zaak van de rol moet worden gevoerd opdat de P-G bij de Hoge Raad een nieuwe dagaanzegging voor de behandeling van het cassatieberoep doet uitgaan. De conclusie A-G bevat een uit- voerige verhandeling over de betekening van de aanzegging in de Koninkrijkslanden Nederland, Aruba, Curaçao en Sint Maarten.

\section{Rolbeslissing}

naar aanleiding van het beroep in cassatie tegen een vonnis van het Gemeenschappelijk Hof van Justitie van Aruba, Curaçao, Sint Maarten en van Bonaire, Sint Eustatius en Saba, van 16 september 2016, nummer H-4/15, in de strafzaak tegen [verdachte].

\section{Geding in cassatie}

Het beroep is ingesteld door de verdachte.

De Advocaat-Generaal E.J. Hofstee heeft geconcludeerd dat de zaak van de rol zal worden gevoerd opdat de Procureur-Generaal bij de Hoge Raad een nieuwe dagaanzegging voor de behandeling in cassatie doet uitgaan.

\section{Beoordeling van de geldigheid van de}

\section{dagaanzegging}

Op grond van hetgeen in de conclusie van de Advocaat-Generaal is vermeld moet worden aangenomen dat de uitreiking van de dagaanzegging als bedoeld in art. $435 \mathrm{~Sv}$ niet op rechtsgeldige wijze heeft plaatsgevonden. Dit leidt ertoe dat de onderhavige zaak van de rol moet worden gevoerd opdat de Procureur-Generaal bij de Hoge Raad een nieuwe dagaanzegging voor de behandeling van het cassatieberoep doet uitgaan.

\section{Beslissing}

De Enkelvoudige Kamer van de Hoge Raad voert de zaak van de rol.

\section{Conclusie}

mr. E.J. Hofstee

1. Het Gemeenschappelijk Hof van Justitie van Aruba, Curaçao, Sint Maarten en van Bonaire, Sint Eustatius en Saba (verder: het Gemeenschappelijk Hof) heeft bij strafvonnis van 16 september 2015 bevestigd het strafvonnis van het Gerecht in eerste 
aanleg van Sint Maarten, waarbij de verdachte, blijkens de strafvonnissen (toen) wonende te Sint Maarten aan de [a-straat 2], wegens 'overtreding van een bij artikel 3 van de Vuurwapenverordening 1930 gesteld verbod, meermalen gepleegd', is veroordeeld tot een gevangenisstraf voor de duur van 12 maanden, waarvan 4 maanden voorwaardelijk met een proeftijd van 2 jaren, en waarbij inbeslaggenomen voorwerpen (een pistool en 7 patronen) zijn onttrokken aan het verkeer.

2. Namens de verdachte is op 29 september 2015 door mr. R.M. Stomp bij de Substituut-Griffier van het Gemeenschappelijk Hof tijdig beroep in cassatie ingesteld tegen het onder 1 genoemde strafvonnis van het Gemeenschappelijk Hof.

3. De desbetreffende stukken van het geding zijn op 5 april 2016 ter griffie van de Hoge Raad ontvangen. 4. De aanzegging als bedoeld in art. 435, eerste lid, $\mathrm{Sv}$ is door het parket van de procureur-generaal bij de Hoge Raad der Nederlanden op 13 april 2016 naar de verdachte verstuurd op het adres [a-straat 2] Sint Maarten. Voorts is namens de procureur-generaal bij de Hoge Raad op 13 april 2016 de voor de verdachte bestemde aanzegging - met een begeleidend verzoek tot betekening - in het Nederlands en in het Spaans verzonden aan het Parket van de Officier van Sint Maarten.

5. Ter griffie van de Hoge Raad is echter geen schriftuur ontvangen binnen de wettelijke termijn (daarover later meer).

6. De vraag doet zich voor of de aanzegging op de juiste wijze aan de verdachte in Sint Maarten is betekend.

7. Het komt mij dienstig voor aan de beantwoording van die vraag enkele beschouwingen te laten voorafgaan.

8. Zo verdient allereerst vermelding dat met ingang van 10 oktober 2010 de staatkundige structuur binnen het Koninkrijk der Nederlanden is gewijzigd als gevolg van een proces van herbezinning. Naar luid van het huidige art. 1 van het Statuut voor het Koninkrijk der Nederlanden is ons Koninkrijk sindsdien samengesteld uit vier landen, te weten Neder- land, Aruba, Curaçao en Sint Maarten ${ }^{10}$; de Nederlandse Antillen zijn op die historische datum opgeheven.

9. Elk van de Koninkrijklanden heeft eigen wetgeving, zo onder meer op strafvorderlijk gebied. Niettemin wordt daarbij naar eenheid in regelgeving gestreefd. Art. 39, eerste lid, van het Statuut brengt die doelstelling tot uitdrukking: het burgerlijk en handelsrecht, de burgerlijke rechtsvordering, het strafrecht en de strafvordering in Nederland, Aruba, Curaçao en Sint Maarten worden 'zoveel mogelijk op overeenkomstige wijze’ geregeld. Concordantie van wetgeving maakt bijgevolg de onderlinge interregionale hulp en bijstand een stuk eenvoudiger. Het bindende concordantiebeginsel is voor de Caribische landen nader uitgewerkt in de 'Samenwerkingsregeling eenvormig procesrecht Aruba, Curaçao en Sint Maarten', die haar juridische grondslag vindt in art. 38, eerste lid, van het Statuut. ${ }^{11}$ Een aangelegenheid die wordt geregeld bij eenvormige landsverordening is het strafprocesrecht, aldus art. 3 van deze Samenwerkingsregeling dat daarmee de lijn van art. 39, eerste lid, van het Statuut voortzet. De Nota van toelichting bij de Samenwerkingsregeling legt nog eens uit waar het hier om gaat en wat eenvormig in dit verband betekent: te bereiken dat de landsverordening in elk van de Caribische landen 'een gelijkluidende tekst heeft en moet blijven houden'. ${ }^{12}$ Strokend met deze belangrijke instructie zijn de wetboeken van strafvordering van Aruba, Curaçao en Sint Maarten nagenoeg woordelijk op elkaar

10 Tot 10 oktober 2010 bestond het Koninkrijk der Nederlanden uit Nederland, de Nederlandse Antillen (Bonaire, Curaçao, Saba, Sint Eustatius en Sint Maarten) en Aruba, aan welk Land al op 1 januari 1986 de status aparte was toegekend. Bonaire, Sint Eustatius en Saba - de zogenoemde BES-eilanden - maken met ingang van 10 oktober 2010 als openbare lichamen in de zin van art. 134 Grondwet deel uit van het Nederlandse staatsbestel.

11 Zie daarover Arjen van Rijn en Lodewijk Rogier (red.), Wetgeving staats- en bestuursrecht voor Sint Maarten, 2014, p. 203-212.

12 Het orgaan dat hiervoor zorg dient te dragen is de Ministeriële Samenwerkingsraad, die uit de Ministerpresident en twee ministers van elk van de drie landen bestaat. 
afgestemd $^{13}$; voor elk van deze landen geldt inmiddels dat een nieuwe 'Landsverordening houdende wijziging van het Wetboek van Strafvordering' tot stand is gekomen. ${ }^{14}$ Men wil evenwel een stap verder gaan. Op dit moment is in voorbereiding een nieuw Wetboek van Strafvordering voor het Caribisch gebied. Het (tweede) concept is al gereed, en zo ook de concept-toelichting. Ik kom daarop later in deze conclusie terug.

10. Eerst wil ik nog wijzen op de bijzondere positie van de Hoge Raad der Nederlanden als cassatierechter in het Koninkrijk. Er is niet alleen sprake van concordantie van wetgeving, maar ook van concordantie van rechtspraak. Van Dorst schrijft dat in de memorie van toelichting bij de voormalige Cassatieregeling voor de Nederlandse Antillen valt te lezen dat het openstellen van cassatieberoep in (toen nog, EH) Antilliaanse rechtszaken onder meer op de grond steunde 'dat justitiabelen in dat land (de Nederlandse Antillen, EH) daardoor meer rechtswaarborgen verkrijgen en dat de concordantie van de rechtspraak, welke een complement is van de concordantie van wetgeving, daardoor wordt bevorderd'. ${ }^{15}$ Voor het Caribische deel van het Koninkrijk geldt op dit moment de 'Rijkswet cassatierechtspraak voor Aruba, Curaçao, Sint Maarten en voor Bonaire, Sint Eustatius en Saba' van 7 juli 2010 (Stb. 339). Ingevolge het eerste lid van art. 1 van deze Rijkswet neemt de Hoge Raad ten aanzien van burgerlijke en strafzaken in de genoemde Koninkrijksdelen, voor zover in de Rijkswet niet anders is bepaald, in overeenkomstige gevallen, op overeenkomstige wijze en met overeenkomstige rechtsgevolgen als ten aanzien van burgerlijke en strafzaken in het Europese deel van het Koninkrijk, kennis van een beroep in cassatie, ingesteld hetzij door partijen,

13 Zie H. de Doelder, 'Algemeen overzicht', in: H. de Doelder (red.), Strafrecht in de Antillen na '10-10-10', 2010, p. 5-10.

14 Zie daarover: J.H.J. Verbaan \& R.J. Verbeek, 'Bijzondere opsporingsbevoegdheden in Curaçao', Caribisch Juristenblad, 2012-3.

15 A.J.A. van Dorst, Cassatie in strafzaken, achtste druk 2015, p. 155. Zie in algemene zin: A.E.M. Röttgering, Cassatie in strafzaken. Een rechtsbeschermend perspectief, 2013 (p. 94). hetzij 'in het belang der wet' door de procureurgeneraal bij de Hoge Raad. ${ }^{16}$ Uitgangspunt is dat in de Caribische landen van het Koninkrijk - of ruimer: het Caribische deel van het Koninkrijk $\mathrm{k}^{17}$ - de Nederlandse cassatievoorschriften als richtsnoer dienen. Vandaar dat de Hoge Raad in zijn arresten in beginsel alleen verwijst naar - via art. 1 van de Rijkswet cassatierechtspraak - toepasselijke Nederlandse cassatievoorschriften, aldus Van Dorst, die daaraan meteen toevoegt: 'Indien bijvoorbeeld geen cassatieschriftuur is ingediend, wordt overwogen dat niet in acht is genomen het voorschrift van art. 437 lid $2 \mathrm{~Sv}$ (dus zonder de toevoeging 'in verbinding met art. 1 lid 1 Cassatieregeling NA', thans art. 1 lid 1 van de Rijkswet cassatierechtspraak)'. ${ }^{18}$

11. Art. 11, derde lid, van de Rijkswet rechtsmacht Hoge Raad voor Aruba, Curaçao, Sint Maarten en voor Bonaire, Sint Eustatius en Saba bepaalt dat aanzeggingen en kennisgevingen als voorgeschreven in Titel III van het Derde Boek van het Wetboek van Strafvordering van het Europese deel van het Koninkrijk op de in Aruba, Curaçao, Sint Maarten en in de openbare lichamen Bonaire, Sint Eustatius en Saba gebruikelijke wijze geschieden, en, voor zover zij moeten uitgaan van de procureur-generaal bij de Hoge Raad, op diens uitnodiging door de zorg van een procureur-generaal bij het Gemeenschappelijk Hof van Justitie. ${ }^{19}$ De wijze waarop aanzeggingen in de Caribische landen behoren te geschieden, heeft elk van deze landen - dus ook Sint Maarten geregeld in de artikelen 642 tot en met 647 van het eigen Wetboek van Strafvordering. Op deze artikelen zal ik straks nader ingaan.

16 Zie voor een overzicht van de cassatierechtspraak op strafrechtelijk gebied: N. Jörg \& P.S. Lambertina, 'Cassatierechtspraak in de Nederlandse Antillen; een overzicht van de laatste tien jaar', in: H. de Doelder (red.), Strafrecht in de Antillen na '10-10-10', 2010, p. 61-88.

17 Waaronder tevens zijn begrepen de openbare lichamen Bonaire, Saba en Sint Eustatius.

18 Van Dorst, a.w., p. 156.

19 In dezelfde zin art. 11, vierde lid, van de voormalige Cassatieregeling voor de Nederlandse Antillen en Aruba. 
12. In de cassatieprocedure - en meer in het bijzonder in de onderhavige zaak - speelt art. 437, tweede lid, Sv (Nederland) een belangrijke rol, naast art. 435, eerste lid, Sv, waarin de aanzegging is geregeld. De wettekst van deze bepalingen luidt als volgt:

(Art. 437, tweede lid, Sv) 'De verdachte door of namens wie beroep is ingesteld, is op straffe van niet-ontvankelijkheid verplicht binnen twee maanden nadat de in het eerste lid van art. 435 bedoelde aanzegging is betekend, bij de Hoge Raad door zijn raadsman een schriftuur te doen indienen, houdende zijn middelen van cassatie.'

(Art. 435, eerste lid, Sv) 'Na ontvangst van de stukken van het geding door de griffier van de Hoge Raad wordt door de procureur- generaal aan de verdachte dan wel, indien door het openbaar ministerie beroep in cassatie is ingesteld, aan het openbaar ministerie en aan de verdachte aangezegd dat de stukken van het geding bij de Hoge Raad zijn ingekomen onder mededeling dat de zaak door de Hoge Raad in behandeling zal worden genomen na verloop van de in het tweede onderscheidenlijk eerste lid van artikel 437 bedoelde termijn. In de aanzegging wordt gewezen op artikel 437.'

13. Het gaat in art. 437, tweede lid, Sv om een zogenoemde 'harde termijn', waarvan het beginpunt dus is gelegen in de datum van betekening van de aanzegging. Indien binnen de gestelde termijn van zestig dagen geen schriftuur wordt ingediend, zal de Hoge Raad de verdachte in het beroep niet-ontvankelijk verklaren. Het spreekt daarom voor zich dat telkens zorgvuldig moet worden gecontroleerd en vastgesteld dat de aanzegging op rechtsgeldige wijze is betekend..$^{20}$ Dit belang in het cassatiegeding klemt te meer indien wordt bedacht dat over die betekening zelf in cassatie niet kan worden geklaagd. ${ }^{21}$ Uiteindelijk is het de rolraadsheer die over de rechtsgeldigheid van de aanzegging beslist. Kleeft aan de

20 Zie daarover Van Dorst, a.w., p. 81.

21 Een dergelijk klacht keert zich immers niet tegen een handeling of beslissing van een rechter als bedoeld in art. 78, eerste lid, RO en levert derhalve geen middel van cassatie in de zin der wet op (HR 24 juni 2008, ECLI:NL:HR:2008:BD0448; HR 4 juli 2000, ECLI:NL: HR:2008:AA6375, NJ 2000/581). betekening een gebrek of onzekerheid, dan wordt de zaak van de rol gehaald en vindt een nieuwe betekening plaats. ${ }^{22}$

14. De anzegging is een gerechtelijk schrijven, waarvan de wijze van uitreiking en betekening nader is geregeld in de eigen wetgeving van elk van de Koninkrijkslanden. In de onderhavige zaak zal dan ook naar de strafvordering van Sint Maarten moeten worden beoordeeld of de aanzegging correct aan de verdachte is betekend. Dat zal ik in deze conclusie nagaan.

15. Ik wil evenwel van de gelegenheid gebruik maken om het onderwerp breder te trekken en vergelijkenderwijs te bezien hoe de betekening van de aanzegging in de andere Koninkrijklanden is geregeld, ofschoon gelet op de concordantieplicht en de hierboven vermelde Samenwerkingsregeling ervan mag worden uitgegaan dat de regelgeving te dezen niet noemenswaardig van elkaar zal afwijken. Verder zal ik daarbij aandacht besteden aan het reeds genoemde voorontwerp van een nieuw Wetboek van Strafvordering voor het Caribisch gebied.

16. In het Wetboek van Strafvordering van Sint Maarten voorzien de artikelen 642 tot en met 647 in de wijze van kennisgeving van gerechtelijke mededelingen aan natuurlijke personen. Deze artikelen houden het volgende in.

16.1. De kennisgeving geschiedt in beginsel door toezending van een gewone of aangetekende brief over de post (art. 642). Vervolgens regelt art. 643 in vijf leden de betekening en uitreiking. Zo worden dagvaardingen en aanzeggingen die aan het openbaar ministerie zijn opgedragen steeds betekend (tweede lid), en wel door uitreiking van het gerechtelijk schrijven door een deurwaarder of een ambtenaar van politie in opdracht van het openbaar ministerie (derde en vierde lid). Wordt de verdachte noch een van diens huisgenoten aan zijn woon- of

22 Van Dorst, a.w., p. 81. Zie bijvoorbeeld HR 16 december 2003, ECLI:NL:HR:2003:AO0068: met het oog op art. 588, tweede lid, Sv stond niet met voldoende zekerheid vast dat de verdachte in Turkije woonde aan het door hem opgegeven adres, zodat er aanleiding was te bepalen dat opnieuw een aanzegging aan de verdachte werd uitgereikt. 
verblijfplaats aangetroffen, dan stelt de met de betekening belaste ambtenaar een afschrift van het gerechtelijk schrijven terstond ter hand aan de officier van justitie bij het gerecht in eerste aanleg waar de rechter, waarvoor gedagvaard wordt, zitting houdt (vijfde lid). ${ }^{23}$ De officier van justitie zal het oorspronkelijk schrijven voor gezien tekenen en het afschrift zo mogelijk aan de verdachte doen toekomen, zonder dat van ontvangst door deze in rechte zal behoeven te blijken (vijfde lid).

16.2. De verdachte die in Sint Maarten rechtens zijn vrijheid is ontnomen in verband met zijn strafzaak, krijgt de aanzegging in persoon uitgereikt. Is de verdachte niet gedetineerd, dan wordt in persoon uitgereikt of, als betekening in persoon niet is vereist en het stuk in Sint Maarten aangeboden wordt aan de woon- of verblijfplaats van de verdachte en hij daar niet aangetroffen wordt, aan degene die zich in het woonhuis bevindt en die zich bereid verklaart om het stuk onverwijld aan de verdachte te doen toekomen. Onder woon- of verblijfplaats wordt mede begrepen het adres waarop de persoon voor wie het schrijven bestemd is op de dag van aanbieding stond ingeschreven in het bevolkingsregister. In het belang van een goede uitvoering van de voormelde artikelen kunnen bij of krachtens Landsbesluit, houdende algemene maatregelen, nadere voorschriften worden gegeven (art. 645).

16.3. Hoe als de verdachte geen bekende woon- of verblijfplaats in Sint Maarten heeft? In dat geval geschiedt de betekening van het gerechtelijk schrijven door middel van aanplakking van het afschrift aan het gebouw, waar de rechter waarvoor gedagvaard wordt, zitting houdt (art. 643, zesde lid).

16.4. Art. 646 schrijft voor dat van iedere uitreiking, als bedoeld in art. 643, een akte wordt opgemaakt, waarin zijn vermeld:

23 Indien uit de gedingstukken niet blijkt dat een afschrift van de dag-aanzegging ter hand is gesteld aan de desbetreffende officier van justitie, zodat deze niet in staat is gesteld om een afschrift aan de woonof verblijfplaats van de verdachte toe te sturen (zie het vervolg in de hoofdtekst), is de uitreiking niet rechtsgeldig en dus nietig, en wordt de zaak in de cassatiefase van de rol gevoerd. Zie HR 28 mei 2002, ECLI:NL:HR:2002:AE1752. a. de autoriteit van welke het schrijven uitgaat;

b. het nummer van het schrijven;

c. de persoon voor wie het schrijven bestemd is;

d. de persoon aan wie het is uitgereikt;

e. de ambtenaar die het heeft uitgereikt;

f. de plaats van uitreiking;

g. de dag en het uur van uitreiking (eerste lid). De akte wordt door hen die met de uitreiking zijn belast, ieder voor zover het zijn bevindingen en handelingen betreft, ter plaatse van die bevindingen en handelingen in persoon opgemaakt op de eed afgelegd bij de aanvaarding van hun bediening en terstond ondertekend (tweede lid).

16.5. Tot slot bepaalt art. 647 dat de betekening nietig is, indien de uitreiking niet heeft plaatsgehad overeenkomstig het bepaalde in de artikelen 643, 644 en 646 (eerste lid), zij het dat de nietigheid wordt gedekt door vrijwillige verschijning ter zitting van degene voor wie het schrijven bestemd is (tweede lid). Indien de akte bijvoorbeeld wel de dag en niet het uur van uitreiking vermeldt, is de beteke- 
ning van de dag-aanzegging nietig ${ }^{24}$, tenzij het belang van de verdachte niet is geschaad, bijvoorbeeld indien de aanzegging in persoon is geschied en de verdachte tijdig ervan op de hoogte is gesteld wanneer de zaak in cassatie ter terechtzitting van de Hoge Raad zal worden behandeld. ${ }^{25}$

16.6. De betekeningsartikelen in het Arubaanse Wetboek van Strafvordering ${ }^{26}$ en die in het Curaçaose Wetboek van Strafvordering ${ }^{27}$ zijn beide gelijkluidend aan die van Sint Maarten, hetgeen

24 Zie HR 28 mei 2002, ECLI:NL:HR:2002:AE3251. Ik citeer daaruit: "1.6. Uit de toelichting bij het ontwerp van het Wetboek van Strafvordering voor de Nederlandse Antillen volgt dat in beginsel de regeling inzake kennisgeving van gerechtelijke mededelingen is overgenomen uit de Nederlandse Wet van 24 april 1985, Stb. 236, zij het dat de indeling der artikelen enigszins anders is opgezet. Een belangrijk verschil met de Nederlandse regeling is, dat de uitreiking niet over de post, maar door de deurwaarder of een ambtenaar van politie geschiedt. Uit de wetsgeschiedenis van art. 589 Sv, waarbij art. 646 SvNA aansluit, blijkt omtrent het belang van de vermelding van het uur van uitreiking het volgende: "De vermelding van het uur van uitreiking in de acte zal o.m. in staat stellen te controleeren, of de postambtenaar, bij uitreikingen niet in persoon, werkelijk bij eenige opeenvolgende bestellingen getracht heeft aan den betrokkene in persoon uit te reiken." (Bijl. Hand. II, 1934-1935, 362.6, blz. 267, rk). Uit die passage valt af te leiden dat het voorschrift omtrent de vermelding van het uur van betekening in het bijzonder is gegeven voor die gevallen waarin de uitreiking niet in persoon geschiedt, zodat ditzelfde kan worden aangenomen voor het bepaalde in art. 646, eerste lid aanhef en onder g, SvNA. Bij die stand van zaken moet het ervoor worden gehouden dat, nu de aanzegging niet in persoon is geschied, de betekening van de dagaanzegging nietig is." Dat leidde in de cassatieprocedure ertoe dat de zaak van de rol werd gevoerd en de procureur-generaal bij de Hoge Raad diende zorg te dragen voor een nieuwe dag-aanzegging voor de behandeling in cassatie.

25 HR 28 mei 2002, ECLI:NL:HR:2002:AE1733.

26 Landsverordening van 24 oktober 1996 houdende vaststelling van een nieuw Wetboek van Strafvordering van Aruba, 28 november 1996, Afkondigingsblad van Aruba 1996 no. 75 en Landsverordening van 31 juli 1997 houdende nadere bepalingen etc., 20 augustus 1997, Afkondigingsblad van Aruba 1997 no. 34 . gelet op de eerdergenoemde concordantieplicht en de hierboven genoemde Samenwerkingsregeling niet verwonderlijk is. ${ }^{28}$

16.7. Als meermalen gezegd, zijn op dit moment een voorontwerp van een nieuw Caribisch Wetboek van Strafvordering en de toelichting daarbij aanhangig. Ik benadruk echter dat het vooralsnog om ambtelijke stukken gaat. ${ }^{29}$ Ten opzichte van de huidige strafvorderlijke wetsbepalingen in de West, is voorontwerp-art. 642 iets uitgebreid: de kennisgeving van gerechtelijke mededelingen aan natuurlijke personen geschiedt door a. betekening, b. toezending of c. mondelinge mededeling. Blijkens de concept-toelichting is de betekening alleen in speciale, bij wet bepaalde gevallen vereist. ${ }^{30}$ De betekening is nader uitgewerkt in voorontwerp-art. 643, waarvan het tweede lid luidt: 'Dagvaardingen en aanzeggingen die aan het openbaar ministerie zijn opgedragen, worden steeds betekend.' Daarmee is een deurwaarder of een ambtenaar van politie belast (lid 3), in opdracht van het openbaar ministerie, dan wel - en dit zou nieuw zijn - van een bij of krachtens

27 Vgl. de Landsverordening van 5 november 1996 houdende vaststelling van een nieuw Wetboek van Strafvordering, Publicatieblad A ${ }^{\circ} 1996, \mathrm{~N}^{\circ} 164$, de Landsverordening van 11 september 1997 houdende bepalingen in verband met de invoering van het nieuwe Wetboek van Strafverordening (Invoeringslandsverordening wetboek van strafvordering), Publicatieblad $\mathrm{A}^{\circ} 1997, \mathrm{~N}^{\circ} 237$ en het Landsbesluit van 25 september 1997, no. 13, regelende de inwerkingtreding van de Invoeringslandsverordening wetboek van strafvordering (P.B. 1997, no. 237), Publicatieblad A 1997 , $\mathrm{N}^{\circ} 251$.

28 Terzijde merk ik op dat in het Arubaanse wetboek van "Aruba" wordt gesproken en in die van Curaçao en Sint Maarten (nog) van "de Nederlandse Antillen".

29 Het eerste concept dateert van 2013. In januari 2017 is het tweede, aangevuld concept verschenen. Wat betreft de Vijfde Afdeling "Wijze van kennisgeving van gerechtelijke mededelingen aan natuurlijke personen", is in het tweede concept geen verandering aangebracht (op één hoofdletter na). In Curaçao en Sint Maarten liggen de (gelijkluidende) concepten reeds bij de eigenlandelijke Raad van Advies.

30 Het vereiste geldt bijvoorbeeld niet bij de oproeping van getuigen. Dan kan worden volstaan met toezending of een mondelinge mededeling. 
Landbesluit aangewezen instantie (lid 4). De gerechtelijke mededeling wordt in persoon uitgereikt indien de betrokkene gevangen zit in het Koninkrijk (lid 5 aanhef en onder a). Ook dit is een uitbreiding. Natuurlijk kan de gerechtelijke mededeling ook aan de niet-gedetineerde verdachte bij hem thuis in persoon worden betekend. Indien hij daar niet wordt aangetroffen, kan een ander die zich op het adres bevindt en die zich daartoe bereid verklaart het stuk in ontvangst nemen teneinde het onverwijld aan de betrokkene te overhandigen. Wenst die ander het stuk niet te aanvaarden, dan wordt een schriftelijk bericht bij of in het huis achtergelaten dat de betrokkene of een daartoe gemachtigde het stuk kan ophalen bij het parket, hetgeen als een betekening in persoon wordt aangemerkt. Voor alle zekerheid zendt het openbaar ministerie een kopie van de schriftelijke mededeling naar het adres van de verdachte. ${ }^{31}$ Op deze wijze wordt aangenomen dat het stuk de verdachte in het Land heeft bereikt, dan wel daar heeft kunnen bereiken. Uiteraard ligt het anders wanneer de verdachte geen bekende woon- of verblijfplaats heeft in het Land. Op die variant heeft het zevende lid van concept-art. 643 betrekking: een afschrift van het gerechtelijk schrijven wordt aangeplakt aan het gebouw waar de rechter waarvoor gedagvaard wordt, zitting houdt. De dag van aanplakking geldt als betekeningsdatum, zo verduidelijkt de concept-toelichting. Is er een adres van de verdachte in een ander Land (dus binnen het Caribisch gedeelte van ons Koninkrijk, EH) bekend, dan 'wordt de zaak tijdig doorgezonden naar het openbaar ministerie ter overhandiging in het andere Land' opdat de uitreiking daar dan volgens dezelfde route als hierboven beschreven plaatsvindt (lid 8). Bij een bekende verblijfplaats buiten het Koninkrijk, wordt betekend door toezending van de mededeling van het openbaar ministerie hetzij rechtstreeks hetzij door tussenkomst van de bevoegde autoriteit of instantie en, voor zover een verdrag van toepassing is, met inachtneming van dat verdrag (lid 8).

31 Het moment van zending door het openbaar ministerie geldt als de betekeningsdatum, aldus de concepttoelichting.
16.8. Dan de Nederlandse regeling. Art. 585, eerste lid, Sv maakt kennisgeving van gerechtelijke mededelingen aan natuurlijke personen mogelijk door a. betekening, b. toezending of c. mondelinge mededeling. Ingevolge het tweede lid geschiedt de betekening door uitreiking van een gerechtelijk schrijven op de bij de wet voorziene wijze. Aanzeggingen die aan het openbaar ministerie of de procureur-generaal bij de Hoge Raad zijn opgedragen, worden steeds betekend, tenzij de wet anders bepaalt of toelaat (art. 586, eerste lid, Sv). Het gerechtelijk schrijven, bedoeld in art. 585, tweede lid, Sv wordt uitgereikt door de post of in spoedeisende gevallen, dan wel indien dit om enige andere reden wenselijk is, door een daarvoor in aanmerking komende politieambtenaar of daartoe aangewezen andere ambtenaar of functionaris indien daartoe opdracht is gegeven door het openbaar ministerie (art. $587 \mathrm{~Sv}$ ). De belangrijkste bepalingen in het onderhavige verband zijn echter te vinden in art. $588 \mathrm{~Sv}$, dat handelt over de wijze waarop de uitreiking dient plaats te vinden. In het arrest van HR 12 maart 2002, ECLI:NL:HR:2002:AD5163, NJ2002/317 m.nt. Schalken geeft de Hoge Raad het volgende overzicht van de betekeningsvoorschriften ingevolge art. $588 \mathrm{~Sv}$ :

'B. De verdachte heeft een bekend adres in Nederland

a. De verdachte heeft een GBA-adres

3.10. Uit hetgeen hiervoor onder 3.2 is overwogen volgt dat - behoudens in het hiervoor onder 3.8 genoemde geval waarin de betekening van de dagvaarding aan de verdachte in persoon is voorgeschreven - zijn GBA-adres als uitgangspunt dient te worden genomen bij de betekening van de dagvaarding.

3.11. Indien de verdachte is ingeschreven in een GBA is de betekening in elk geval geldig indien de dagvaarding is aangeboden aan zijn GBA-adres en - omdat hij aldaar niet werd aangetroffen - is uitgereikt aan iemand die zich op dat adres bevond en zich bereid verklaarde de dagvaarding onverwijld aan de verdachte te doen toekomen (art. 588 lid 3 sub a). 
Daarbij moet worden aangetekend dat een dergelijke bereidverklaring alleen rechtsgeldig kan worden gedaan in geval van aanbieding aan het GBAadres van de verdachte. Dit betekent dat in geval van aanbieding aan een adres waarop de verdachte niet staat ingeschreven in de GBA, terwijl van hem wel een inschrijving elders in een GBA bekend is, de dagvaarding op eerstgenoemd adres slechts aan hem in persoon kan worden uitgereikt of, na achterlating van een bericht van aankomst op de daarin vermelde plaats, aan de verdachte in persoon dan wel aan een door hem daartoe mondeling of schriftelijk gemachtigde.

3.12. De omstandigheid dat bij de aanbieding van de dagvaarding aan het GBA-adres van de verdachte aldaar iemand aanwezig blijkt te zijn die mededeelt dat de verdachte daar niet woont of verblijft, of die zich niet bereid verklaart het stuk onverwijld aan de geadresseerde te doen toekomen, staat niet in de weg aan de geldigheid van de latere - hierna onder 3.15 nog te bespreken - betekening door middel van uitreiking van de dagvaarding aan de griffier. Dergelijke mededelingen nopen evenmin tot het instellen van een nader onderzoek naar de feitelijke woon of verblijfplaats van de verdachte.

3.13. Na de vergeefse aanbieding aan het GBA-adres van de verdachte kan de dagvaarding rechtsgeldig worden betekend door uitreiking aan iemand die door de verdachte schriftelijk of mondeling is gemachtigd tot het in ontvangst nemen van de dagvaarding op de plaats die is vermeld in het op het GBA-adres achtergelaten bericht van aankomst (art. 588 lid 3 sub b).

3.14. Daarbij verdient opmerking dat een dergelijk bericht van aankomst slechts behoeft te worden achtergelaten indien op het GBA-adres waar de dagvaarding is aangeboden, niemand is aangetroffen. Dat bericht behoeft dus niet te worden achtergelaten indien de desbetreffende woning niet (meer) bestaat, dan wel door iemand die zich op dat adres bevond is medegedeeld dat de verdachte daar niet woont of verblijft.

3.15. Wanneer geen uitreiking heeft kunnen geschieden, wordt de dagvaarding teruggestuurd naar de autoriteit van welke zij is uitgegaan. Vervol- gens kan zij worden uitgereikt aan de griffier van de rechtbank van het arrondissement waarbinnen de zaak zal dienen. De dagvaarding is dan rechtsgeldig betekend op voorwaarde dat bij adresverificatie blijkt dat de verdachte op de dag waarop de dagvaarding op het GBA-adres is aangeboden en tenminste vijf dagen nadien op dat adres was ingeschreven. De griffier zendt vervolgens de dagvaarding onverwijld als gewone brief over de post aan het GBA-adres (art. 588 lid $3 \mathrm{sub}$ c), ook indien de verdachte ten tijde van die verzending niet meer op dat adres was ingeschreven. Indien evenwel blijkt dat de verdachte gedurende die termijn van vijf dagen naar een ander GBA-adres is overgeschreven, dient de betekeningsprocedure opnieuw een aanvang te nemen. Blijkt dat hij in die termijn van vijf dagen is vertrokken 'onbekend waarheen', dan dient te worden gehandeld als hierna onder $3.23-3.25$ vermeld.

3.16. Benadrukt moet worden dat het gaat om het GBA-adres waarop de verdachte in de GBA stond ingeschreven op het tijdstip van de vergeefse aanbieding en binnen vijf dagen daarop volgend. Aan de geldigheid van de betekening door middel van uitreiking van de dagvaarding aan de griffier doet dus niet af:

a dat de verdachte bij zijn verhoor door de politie een andere woon of verblijfplaats heeft opgegeven dan zijn GBA-adres;

b dat het GBA-adres blijkens de opgave van de gemeente 'in onderzoek' is;

c dat de verdachte ten tijde van de uitreiking aan de griffier niet meer woonde of verbleef op dat GBA-adres. Van de verdachte kan immers worden gevergd dat hij ervoor zorgt dat de dagvaarding hem kan bereiken indien hij van adres verandert.

b. De verdachte heeft een feitelijke woon of verblijfplaats in Nederland

3.17. Indien op grond van het daartoe ingestelde onderzoek als vaststaand kan worden aangenomen dat de verdachte niet is ingeschreven in een GBA en niet in Nederland is gedetineerd, is de betekening in elk geval geldig indien de dagvaarding is aangebo- 
den aan de feitelijke woon of verblijfplaats van de verdachte en - omdat hij aldaar niet werd aangetroffen - is uitgereikt aan iemand die zich op dat adres bevond en zich bereid verklaarde de dagvaarding onverwijld aan de verdachte te doen toekomen (art. $588 \operatorname{lid} 3 \mathrm{sub}$ a).

Bij de beantwoording van de vraag of de verdachte een feitelijke woon of verblijfplaats heeft, is het hierna onder 3.24 en 3.25 gestelde van toepassing.

3.18. In geval van vergeefse aanbieding van de dagvaarding aan de feitelijke woon of verblijfplaats van de verdachte zijn de hiervoren onder $3.13-3.15$ vermelde regels van overeenkomstige toepassing, met dien verstande:

a dat het feitelijke woon of verblijfadres in plaats van het GBA-adres van de verdachte als uitgangspunt dient te worden genomen,

b dat de nadere verificatie van het adres in de GBA achterwege kan blijven, en

c dat na uitreiking van de dagvaarding aan de griffier deze - met analogische toepassing van art. 588 lid 3 sub c - de dagvaarding onverwijld als gewone brief over de post aan het feitelijke woon of verblijfadres van de verdachte behoort te zenden.

C. De verdachte heeft een bekend adres in het buitenland

3.19. Indien op grond van het daartoe ingestelde onderzoek als vaststaand kan worden aangenomen dat de verdachte niet is ingeschreven in een GBA en niet in Nederland is gedetineerd, en ook niet een feitelijke woon- of verblijfplaats in Nederland, maar wel een adres in het buitenland bekend is, geschiedt de betekening van de dagvaarding door toezending van de dagvaarding door het openbaar ministerie hetzij rechtstreeks aan het laatstbekende adres van de verdachte in het buitenland, hetzij door tussenkomst van de bevoegde buitenlandse autoriteit of instantie (art. 588 lid 2). Door die toezending is de dagvaarding rechtsgeldig betekend. Als datum waarop die betekening plaatsvindt, geldt de datum van de verzending van de dagvaarding, waarvan aantekening dient te geschieden in de akte van uitreiking. (...)

\subsection{0}

(...)

b. De regeling van art. 588 lid 2 is van overeenkomstige toepassing indien de verdachte geen bekende woon- of verblijfplaats heeft op de Nederlandse Antillen of Aruba. ${ }^{32}$

16.9. Niet voorziet art. $588 \mathrm{~Sv}$ in een bepaling die is toegesneden op de weigering van de verdachte om het stuk in ontvangst te nemen. Dat is in zekere zin opmerkelijk te noemen omdat art. 385, derde lid, Sv inzake het rechtsgeding voor de kantonrechter met die mogelijkheid wel rekening heeft gehouden:

32 Zie eerder al HR 27 februari 2001, ECLI:NL:HR: 2001:AB0264, NJ 2001/323: “3.2.2. Het tweede lid van art. 588 Sv geeft nadere voorschriften voor de uitreiking aan een geadresseerde van wie de woon- of verblijfplaats in het buitenland bekend is. 3.3. Art. $588 \mathrm{~Sv}$ geeft geen voorschriften voor de uitreiking van gerechtelijke stukken aan een geadresseerde die niet in Nederland, noch in het buitenland, maar die niettemin in het Koninkrijk der Nederlanden, namelijk in een van de drie andere landen van het Koninkrijk, een bekende woon- of verblijfplaats heeft. 3.4. Bij ontbreken van enige regeling in het Wetboek van Strafvordering of in een wettelijke regeling ter voorziening in kwesties van interregionaal strafrecht (of interregionale strafvordering) binnen het Koninkrijk der Nederlanden, welke materie ingevolge art. 38, derde lid, van het Statuut voor het Koninkrijk der Nederlanden bij rijkswet behoort te worden geregeld, kan in deze leemte het beste worden voorzien door overeenkomstige toepassing van het tweede lid van art. $588 \mathrm{~Sv}$. Dat betekent dat in gevallen als deze de uitreiking aan een geadresseerde van wie de woon- of verblijfplaats in een van de andere landen van het Koninkrijk bekend is, kan geschieden door rechtstreekse toezending van de mededeling door het parket van de Procureur-Generaal bij de Hoge Raad, dan wel door tussenkomst van de bevoegde autoriteit in het desbetreffende andere land in het Koninkrijk. In het laatstbedoelde geval geldt deze uitreiking als betekening in persoon, zonder dat hiervan nog uit een afzonderlijke akte behoeft te blijken, indien de bevoegde autoriteit of instantie in het desbetreffende land van het Koninkrijk bericht dat de mededeling aan de geadresseerde is uitgereikt." In die zaak bleek de aanzegging niet op geldige wijze te hebben plaatsgevonden, zodat deze van de rol werd gevoerd. Vgl. ook HR 25 september 2001, ECLI:NL:HR:2001:ZD2737, NJ 2002/83. 
'Wordt een oproeping door de verdachte niet aangenomen, dan geldt het tijdstip van de weigering van de verdachte als tijdstip van uitreiking. ${ }^{33} \mathrm{Nu}$ echter art. $588 \mathrm{~Sv}$ zich over de mogelijkheid van weigering en het rechtsgevolg daarvan niet uitlaat, kan in dat verband de weigering niet worden gelijkgesteld aan een uitreiking in persoon, aldus HR 4 december 2007, ECLI:NL:HR:2007:BA7912, NJ 2008/18. In dat arrest had het Hof onder meer geconstateerd dat 'op zijn minst' was gepoogd de stukken aan de verdachte uit te reiken. Die vaststelling bracht volgens de Hoge Raad echter niet zonder meer mee dat sprake was van uitreiking van de dagvaarding in persoon. Ook het oordeel van het hof dat zich een omstandigheid had voorgedaan waaruit voortvloeide dat de dag van de terechtzitting de verdachte tevoren bekend was, was niet zonder meer begrijpelijk. Dat de 'akte' op het politiebureau aan de verdachte was voorgehouden, leverde niet zonder meer een dergelijke omstandigheid op.

17. Ook de betekeningsvoorschriften in de Wetboeken van Strafvordering in de Caribische Koninkrijklanden - waaronder die van Sint Maarten - bieden geen specifieke voorziening voor het geval waarin de verdachte weigert het stuk aan te nemen. Wellicht verdient het aanbeveling de vraag te bezien of het concept-Caribisch Wetboek van Strafvordering te dien aanzien aanpassing behoeft.

18. Terug naar de onderhavige zaak. Onder de voorliggende stukken van het geding heb ik een tweetal originele aktes van uitreiking en één akte van uitreiking in kopie aangetroffen. Deze aktes zijn van verschillende dateringen voorzien.

19. Het origineel van de eerste akte van uitreiking, waaraan gehecht een kopie van de aanzegging en een kopie van de algemene informatie behorende bij de aanzegging, zowel in het Nederlands als in het Spaans, dateert van 15 augustus 2016 (14:35 uur). Deze akte houdt voor zover hier van belang in: 'Parketnummer: 100.00321/14 - S 16/01895 A

De Procureur-Generaal van Curaçao, Sint Maarten en Bonaire, St. Eustatius en Saba

33 De vraag of de weigering kan worden beschouwd als het rechtsgeldig afstand doen van recht, laat ik hier rusten.
Akte van uitreiking van gerechtelijk schrijven: cassatie termijn 60 dagen

Uitgaande van: Procureur-Generaal

Bestemd voor

Naam: [achternaam verdachte]

Voornamen: [voornamen verdachte]

Geboren op: [geboortedatum] 1972 te [geboorteplaats]

Wonende te: Sint Maarten

Adres: [a-straat 1]

Heden 15 augustus 2016 te 14:35 uur, heb ik Woodley Melvin /Deurwaarder, het hierboven bedoeld gerechtelijk schrijven;

(...)

gedagvaard om te verschijnen ten tijde, ter plaatse en tot het doel als in het dagvaarding omschreven, sprekende met en afschrift van het dagvaarding en van deze akte latende aan door plakking van een afschrift hiervan aan de hoofddeur van de gehoorzaal in het Courthouse alwaar het Hof zitting houdt. Deze akte heb ik, de voornoemde Ambtenaar van Politie/Deurwaarder, ter plaatse van mijn bevindingen en handelingen in persoon opgemaakt op ambtseed/ambtsbelofte en terstond ondertekend.

Deurwaarder voorgenoemd, (met handtekening, AG)'

Het origineel van deze akte van uitreiking is op 13 september 2016 op de strafgriffie van de Hoge Raad ingekomen.

20. Dat deze akte blijkens haar inhoud niet juist was uitgereikt, en dat wat al te snel tot de gekozen vorm van dagvaarding was overgegaan, kon al direct op de strafgriffie van de Hoge Raad worden vastgesteld. Dagvaarding door middel van aanplakking van het afschrift aan het Courthouse waar het Hof zitting houdt, geschiedt ook naar het recht van Sint Maarten immers pas nadat gebleken is dat de verdachte geen bekende woon- of verblijfplaats aldaar heeft. In de onderhavige zaak staat in de akte van uitreiking een adres van de verdachte genoemd en dus had op zijn minst een poging tot uitreiking moeten plaatsvinden op dat adres.

21. Het origineel van de tweede akte van uitreiking (d.d. 20 september 2016), waaraan gehecht een kopie van de aanzegging en een kopie van de alge- 
mene informatie behorende bij de aanzegging, wederom zowel in het Nederlands als in het Spaans, bevat de volgende inhoud:

'Parketnummer: 100.00321/14 - S 16/01895 A

De Procureur-Generaal van Curaçao, Sint Maarten en Bonaire, St. Eustatius en Saba

Akte van uitreiking van gerechtelijk schrijven: cassatie termijn 60 dagen

Uitgaande van: Procureur-Generaal

Bestemd voor

Naam: [achternaam verdachte]

Voornamen: [voornamen verdachte]

Geboren op: [geboortedatum] 1972 te [geboorteplaats]

Wonende te: Sint Maarten

Adres: [a-straat 1]

Heden 20 september 2016 te 14:00 uur, heb ik Woodley Melvin /Deurwaarder, het hierboven bedoeld gerechtelijk schrijven;

(...)

niet uitgereikt, omdat volgens mededeling van degene die zich op het bovenstaande adres bevond de geadresseerde daar niet woont en daar ook niet verblijft.

Deze akte heb ik, de voornoemde Ambtenaar van Politie/Deurwaarder, ter plaatse van mijn bevindingen en handelingen in persoon opgemaakt op ambtseed/ambtsbelofte en terstond ondertekend.

Deurwaarder voorgenoemd, (met handtekening, AG)'

22. Blijkens een kopie van de akte van uitreiking d.d. 6 oktober 2016 is, mogelijk in vervolg op de eerdere poging om de aanzegging op 20 september 2016 uit te reiken, de verdachte op die dag te 14:10 uur gedagvaard, en wel op de volgende wijze:

'Parketnummer: 100.00321/14 - S 16/01895 A

De Procureur-Generaal van Curaçao, Sint Maarten en Bonaire, St. Eustatius en Saba

Akte van uitreiking van gerechtelijk schrijven: cassatie termijn 60 dagen

Uitgaande van: Procureur-Generaal

Bestemd voor

Naam: [achternaam verdachte]

Voornamen: [voornamen verdachte]
Geboren op: [geboortedatum] 1972 te [geboorteplaats]

Wonende te: Sint Maarten

Adres: [a-straat 1]

Heden 06 oktober 2016 te 14:10 uur, heb ik Woodley Melvin /Deurwaarder, het hierboven bedoeld gerechtelijk schrijven;

(...)

gedagvaard om te verschijnen ten tijde, ter plaatse en tot het doel als in het dagvaarding omschreven, sprekende met en afschrift van het dagvaarding en van deze akte latende aan door plakking van een afschrift hiervan aan de hoofddeur van de gehoorzaal in het Courthouse alwaar het Hof zitting houdt. Deze akte heb ik, de voornoemde Ambtenaar van Politie/Deurwaarder, ter plaatse van mijn bevindingen en handelingen in persoon opgemaakt op ambtseed/ambtsbelofte en terstond ondertekend.

Deurwaarder voorgenoemd,' (met handtekening, AG)

23. Beide laatstgenoemde aktes (met bijlagen) zijn op 31 oktober 2016 bij de strafgriffie van de Hoge Raad binnengekomen.

24. Allereerst merk ik hier op dat in de voormelde aktes telkens als adres van de verdachte [a-straat 1] wordt genoemd. In de stukken van het geding in feitelijke aanleg wordt echter regelmatig (nog) een ander adres van de verdachte genoemd: [a-straat 2]. Ik wijs bijvoorbeeld op de strafvonnissen in eerste aanleg (zie hierboven randnummer 1) en de akte van uitreiking (in persoon) van de dagvaarding in hoger beroep. ${ }^{34}$ Verder is de aanzegging door het parket van de procureur-generaal bij de Hoge Raad naar dat adres gestuurd (zie randnummer 4). In het procesdossier ben ik geen akte van uitreiking van de aanzegging op dat adres tegengekomen. $\mathrm{Nu}$ op grond van de gedingstukken, voor zover in cassatie voorhanden, niet kan worden uitgesloten dat [a-straat 2] het juiste adres van de verdachte is en

34 Ook in de strafkaart van het Openbaar Ministerie wordt met betrekking tot de verdachte niet alleen [a-straat 1] als adres genoemd, maar ook [a-straat 2] als woonplaats. 
'de betekening te veel twijfel oproept', ${ }^{35}$ ben ik van oordeel dat de aanzegging reeds om die reden opnieuw dient te worden betekend.

25. Ook evenwel indien moet worden aangenomen dat [a-straat 1] het juiste adres is, meen ik dat blijkens de aktes van 20 september 2016 (origineel) en 6 oktober 2016 (kopie) de aanzegging niet op de juiste wijze, overeenkomstig de daarvoor geldende voorschriften van het Wetboek van Strafvordering van Sint Maarten is betekend.

26. Hoe had de betekening dan wel moeten geschieden naar de voorschriften van Sint Maarten? Ik heb hierboven al erop gewezen dat de weigering van de verdachte om de akte in ontvangst te nemen, niet in de artikelen 642 tot en met 647 van de respectieve Caribische Wetboeken van Strafvordering is geregeld, noch overigens in het concept-Caribisch Wetboek van Strafvordering. Welnu, hetzelfde geldt voor de situatie waarvan blijkens de tweede akte van betekening (20 september 2016) sprake is, te weten dat iemand die zich op het adres bevindt meedeelt dat de geadresseerde daar niet woont en daar ook niet verblijft. ${ }^{36}$ Die enkele mededeling kan toch geen deugdelijke grond vormen voor de directe gevolgtrekking dat de verdachte dus in het Land geen bekende woon- of verblijfplaats heeft. Nog daargelaten dat die mededeling onwaar kan zijn, speelt in de onderhavige zaak nog het andere adres, [a-straat 2], nadrukkelijk mee. De 'plakking' van het afschrift aan de hoofddeur van de gehoorzaal in het Courthouse waarvan de akte in kopie van 6 oktober 2016 rept, was daarom in dit verband opnieuw te voorbarig, in aanmerking genomen dat uit de stukken niet blijkt van een nadere adresverificatie en de vaststelling dat de verdachte inmiddels geen bekende woon- of verblijfplaats in Sint Maarten meer had. Op dit laatste voortbordurend, zou het meer in de geest van de regeling zijn geweest, indien de redenering zou hebben geluid dat de aanzegging tevergeefs was aangeboden op het adres [a-straat 1] en ingevolge art. 643,

35 Van Dorst, a.w., p. 81. Zie ook hiervoor randnummer 13.

36 Wellicht verdient ook dit aspect nog nadere aandacht in het totstandkomingsproces van het Caribische Wetboek van Strafvordering. vijfde lid, Sv van Sint Maarten een afschrift terstond ter hand was gesteld aan de officier van justitie bij het bedoelde gerecht. Deze had dan het oorspronkelijk schrijven voor gezien kunnen tekenen en, na nader onderzoek naar het juiste adres, het afschrift zo mogelijk aan de verdachte doen toekomen. ${ }^{37} \mathrm{Nu}$ deze weg niet is gevolgd, althans daar ga ik gezien de stukken van uit, luidt ook om die reden de slotsom dat de akte niet rechtsgeldig is betekend.

27. Ik concludeer dat de zaak- [van verdachte] van de rol zal worden gevoerd opdat de procureur-generaal bij de Hoge Raad een nieuwe dag-aanzegging voor de behandeling in cassatie doet uitgaan.

\section{7 juni 2017, 16/01906 A}

(mrs. A.J.A. van Dorst, J. de Hullu, E.F. Faase en T.N.B.M. Spronken

ECLI:NL:HR:2017:1165

Verzuim aftrek uitleveringsdetentie, art. 1:62.1 SrC. Het middel klaagt op zichzelf terecht dat het Hof heeft verzuimd m.b.t. de in uitleveringsdetentie doorgebrachte tijd toepassing te geven aan art. 1:62.1 SrC. Hetgeen is overwogen in ECLI:NL:HR:2013:BZ4478 m.b.t. het bestaan van onvoldoende in rechte te respecteren belang bij vernietiging van de bestreden uitspraak in geval van het verzuim toepassing te geven aan art. 27.1 Sr is hier op overeenkomstige wijze van toepassing. Dat brengt mee dat het middel vruchteloos is voorgesteld.

In de conclusie van de advocaat-generaal is bepleit dat de HR zelf beveelt dat de in uitleveringsdetentie doorgebrachte tijd bij de uitvoering van de gevangenisstraf in mindering wordt gebracht.

37 Vgl. art. 588, derde lid aanhef en onder c, Sv (Nederland): als uitreiking in persoon of aan degene volgens wie de geadresseerde niet op het adres woont of verblijft, niet is gelukt, wordt het stuk geretourneerd aan de autoriteit die het heeft verzonden. Deze zal dan moeten verifiëren of het adres (nog) juist is, met name aan de hand van de BRP. 


\section{Uitspraak}

op het beroep in cassatie tegen een vonnis van het Gemeenschappelijk Hof van Justitie van Aruba, Curaçao, Sint Maarten en van Bonaire, Sint Eustatius en Saba, van 5 april 2016, nummer H-146/15, in de strafzaak tegen [verdachte].

\section{Geding in cassatie}

Het beroep is ingesteld door de verdachte. (...)

De Advocaat-Generaal T.N.B.M. Spronken heeft geconcludeerd tot vernietiging van de bestreden uitspraak, maar uitsluitend wat betreft de duur van de opgelegde gevangenisstraf en voor zover bij het opleggen van de gevangenisstraf is verzuimd ten aanzien van de uitleveringsdetentie art. 31, eerste lid, SrC toe te passen, en dat de Hoge Raad (i) de opgelegde gevangenisstraf zal verminderen in de mate die hem gepast voorkomt en (ii) zal bevelen dat op de opgelegde gevangenisstraf naast de reeds in mindering gebrachte tijd wegens ondergane inverzekeringstelling en voorlopige hechtenis ook de tijd die de verdachte voor de tenuitvoerlegging van het bestreden arrest in het buitenland in detentie heeft doorgebracht in mindering wordt gebracht.

\section{Beoordeling van het eerste middel}

Het middel kan niet tot cassatie leiden. Dit behoeft, gezien art. 81, eerste lid, RO, geen nadere motivering nu het middel niet noopt tot beantwoording van rechtsvragen in het belang van de rechtseenheid of de rechtsontwikkeling.

\section{Beoordeling van het tweede middel}

3.1. Het middel klaagt in de kern genomen dat het Hof ten onrechte geen toepassing heeft gegeven aan art. 1:62, eerste lid, van het Wetboek van Strafrecht van Curaçao (hierna: $\mathrm{SrC}$ ) door bij het opleggen van de gevangenisstraf niet te bepalen dat de tijd die de verdachte heeft doorgebracht in uitleveringsdetentie bij de uitvoering van de straf geheel in mindering zal worden gebracht.

3.2. Het eerste lid van voormeld art. 1:62 luidt, voor zover hier van belang:
'Bij het opleggen van tijdelijke gevangenisstraf, hechtenis of taakstraf beveelt de rechter, dat de tijd die door de veroordeelde vóór de tenuitvoerlegging van de uitspraak in verzekering, in voorlopige hechtenis of in detentie in het buitenland ingevolge een verzoek van Curaçao om uitlevering is doorgebracht, bij de uitvoering van die straf geheel in mindering zal worden gebracht.'

3.3. De stukken van het geding houden in dat de verdachte ingevolge een Curaçaos verzoek om uitlevering enige tijd in detentie in de Verenigde Staten heeft doorgebracht. Het Hof, dat de verdachte heeft veroordeeld tot een gevangenisstraf van twaalf jaren, met aftrek van de tijd doorgebracht in verzekering en in voorlopige hechtenis, heeft evenwel verzuimd met betrekking tot die in uitleveringsdetentie doorgebrachte tijd toepassing te geven aan art. 1:62, eerste lid, SrC. Daarover klaagt het middel op zichzelf terecht.

3.4. Voormeld art. 1:62, eerste lid, $\mathrm{SrC}$ is gelijkluidend aan art. 27, eerste lid, Sr. In zijn arrest van 19 maart 2013, ECLI:NL:HR:2013:BZ4478, NJ 2013/246 heeft de Hoge Raad met betrekking tot de laatstgenoemde bepaling het volgende overwogen:

'Zoals de Hoge Raad heeft overwogen in zijn arresten van 11 september 2012 (LJN BX0146, LJN BX0132, LJN BX0129 en LJN BX7004) behoort het verzuim toepassing te geven aan de in art. $27 \mathrm{Sr}$ bedoelde aftrek tot de verzuimen die voor de invoering van art. 80a RO grond vormden voor vernietiging van de bestreden uitspraak, doch nadien met toepassing van art. 80a RO - of in voorkomende gevallen met toepassing van art. 81, eerste lid, RO - niet langer tot cassatie nopen. Dat berust erop dat bij vernietiging van de bestreden uitspraak niet voldoende in rechte te respecteren belang bestaat. Het verzuim toepassing te geven aan de wettelijk voorgeschreven aftrek als bedoeld in art. 27 Sr vormt immers een onmiddellijk kenbare fout die zich voor eenvoudig herstel leent door de rechter(s) die op de zaak heeft/hebben geze- 
ten overeenkomstig hetgeen de Hoge Raad heeft beslist in zijn arresten van 6 juli 2010 (LJN BJ7243, NJ 2012/248) en 12 juni 2012 (LJN BW1478, NJ 2012/490). Deze wijze van herstel verdient de voorkeur, omdat daardoor ondubbelzinnig duidelijkheid komt te bestaan omtrent de voor tenuitvoerlegging vatbare strafoplegging.

Maar ook indien zodanige herstelbeslissing achterwege blijft, bestaat bij vernietiging van de bestreden uitspraak waarin verzuimd is de aftrek van art. $27 \mathrm{Sr}$ te bevelen onvoldoende in rechte te respecteren belang. Er is in zo een geval immers sprake van een voor eenieder evidente vergissing op grond waarvan die uitspraak verbeterd moet worden gelezen, en wel aldus dat de bedoelde aftrek is bevolen. Een redelijk handelend openbaar ministerie dat met de tenuitvoerlegging van de strafoplegging is belast kan zich dan ook niet op het standpunt stellen dat de straf zonder die aftrek moet worden ten uitvoer gelegd.'

3.5. Het vorenoverwogene is op overeenkomstige wijze van toepassing in geval van het verzuim toepassing te geven aan art. 1:62, eerste lid, SrC. Dat brengt mee dat het middel vruchteloos is voorgesteld.

\section{Beoordeling van het derde middel}

4.1. Het middel klaagt dat de redelijke termijn als bedoeld in art. 6, eerste lid, EVRM in de cassatiefase is overschreden omdat de stukken te laat door het Hof zijn ingezonden.

4.2. Het middel is gegrond. Dit moet leiden tot vermindering van de aan de verdachte opgelegde gevangenisstraf van twaalf jaren.

\section{Slotsom}

$\mathrm{Nu}$ de Hoge Raad geen grond aanwezig oordeelt waarop de bestreden uitspraak ambtshalve zou behoren te worden vernietigd, brengt hetgeen hiervoor is overwogen mee dat als volgt moet worden beslist.

\section{Beslissing}

De Hoge Raad:

vernietigt de bestreden uitspraak maar uitsluitend wat betreft de duur van de opgelegde gevangenisstraf;

vermindert deze in die zin dat deze elf jaren en tien maanden bedraagt;

verwerpt het beroep voor het overige. 